\title{
|| Yetişkinlerin Halk Eğitim Merkezlerindeki Eğitim Faaliyetlerine Olan İstemlerinin Farklı Değişkenler Bakımından İncelenmesi'
}

\author{
Ensar AKTAȘ* \\ Hüseyin YOLCU**
}

\begin{abstract}
Öz: Bu araştırmanın amacı, yetişkin bireylerin eğitim istemleri üzerinde belirleyici olan değişkenleri ortaya koymaktır. Tarama modelinin kullanıldığı bu çalışmanın çalışma grubunu 2018-2019 eğitim öğretim yılında Ankara il merkezinde faaliyet gösteren Halk Eğitimi Merkezlerinin (HEM) açmış olduğu eğitim faaliyetlerine katılan 25 yaş ve üzerindeki 247 katılımcı oluşturmaktadır. Verilerin analizinde yüzde, frekans, ortalama ve standart sapma gibi tanımlayıcı istatistiklerin yanı sıra veri setindeki ilişkileri incelemek için T Testi ve ANOVA testi kullanılmıştır. Araştırmada, yetişkin bireylerin eğitim faaliyetlerine olan istemlerinde daha çok "Sosyal", "Mesleki, "Kendini Geliştirmek" ve "Ekonomik" nedenler belirleyici olmaktadır. Yetişkinlerin bu yöndeki istemleri üzerinde; cinsiyet, yaş, medeni durum, öğrenim düzeyi, mesleki durum, çalışma durumu, aylık gelir ve hanedeki birey sayısı bakımından farklılaşmalar olduğu gözlenmiştir. HEM'lerde yürütülen ekonomik içerikli eğitim faaliyetlerine katılan kadınların, bu süreçten sonraki yaşam döngülerini sorgulamaya yönelik bir araştırma yapılmasıdır. Böylelikle, HEM'lerde verilen bu tür eğitimlerin içeriğinin ve işlevselliğinin de gözden geçirilmesi mümkün olacaktır.
\end{abstract}

Anahtar Sözcükler: Yetişkin, Yetişkin Eğitimi, Eğitim İstemi, Halk Eğitim Merkezi

\section{Investigation of Adults' Demands for Educational Activities in Public Training Centers with Respect to Different Variables}

\begin{abstract}
This study aims to reveal the factors that is determinative in educational demands of adults. The participants of this study in which General Survey Model was used consists of 247 people being over the age of 25 and enrolling in the educational activities of the Public Training Center (PTC) in Ankara (city-centre) in 2018-2019 Academic Year. Descriptive statistics such as percentage, frequency, median value, standard deviation were used to analyze the data as well as T-test and ANOVA tests to analyze the relations in the data set. Results of the present study revealed that "social", "professional", "self-development" and "economic" reasons have been rather determinative in adults' demands for educational activities. Differences in gender, age, marital status, level of education, professional status, employment status, monthly income and the number of household members were found to be influencing the demands of adults in this respect. A further study to investigate the life cycles of women, who enroll in the educational activities provided by PTCs, after this process would be useful, thus, the content and function of education provided by PTCs may be evaluated.
\end{abstract}

Keywords: Adult, Adult Education, Education Demand, Public Training Center

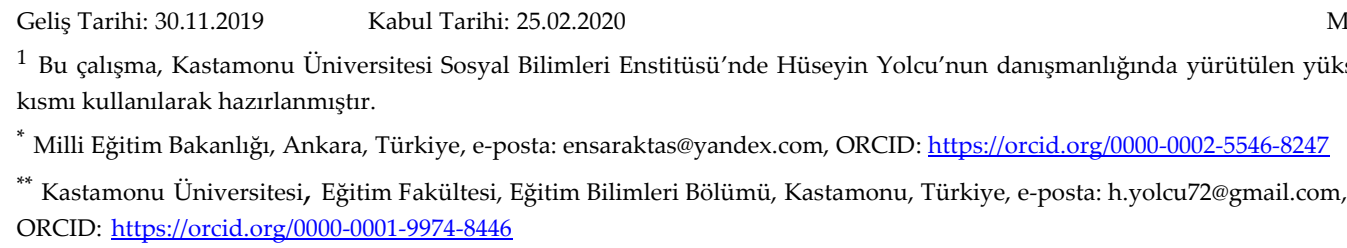
kısmı kullanılarak hazırlanmıştır.

* Milli Eğitim Bakanlığı, Ankara, Türkiye, e-posta: ensaraktas@yandex.com, ORCID: https://orcid.org/0000-0002-5546-8247

** Kastamonu Üniversitesi, Eğitim Fakültesi, Eğitim Bilimleri Bölümü, Kastamonu, Türkiye, e-posta: h.yolcu72@gmail.com, ORCID: https://orcid.org/0000-0001-9974-8446

1 Bu çalışma, Kastamonu Üniversitesi Sosyal Bilimleri Enstitüsü’nde Hüseyin Yolcu'nun danışmanlığında yürütülen yüksek lisans tezinin verilerinin bir 
Bir yaşam evresi olarak yetişkinlik kavramını tam anlamıyla kavramlaştırmakta güçlükler bulunmaktadır. Bunun nedeni, yasaların 18 yaş ve üzeri kişileri yetişkin olarak kabul etmesine karşın yetişkinlik evresinin kültür ve gruplar bakımından farklılık gösterebilmesidir. Örneğin, Bülbül'e (1991) göre; zorunlu eğitim dönemini bitiren kişiler yetişkin olarak kabul edilmektedir. Birleşmiş Milletler Eğitim, Bilim ve Kültür Örgütü (UNESCO, 1985) ise yetişkini, beden yapısı ve düşünce olarak olgun kişi olarak tanımlanmaktadır. Buradan hareketle, yetişkin kişilerden kendi sorumluluklarının farkında olması ve bu sorumluluklarını yerine getirebilmesi, toplum içinde bir konuma sahip olması ve yine sahip olduğu mesleki nitelikleriyle kendi yaşamını sürdürecek davranışları ortaya koyması beklenmektedir (Celep, 2006). Yetişkinlerin kendilerinden beklenilen bu davranışları kazanabilmek için de bu yönde bir eğitim yaşamı geçirmiş olması veya eğitim eksikliğini tamamlamış olması gerekmektedir (Bülbül, 1991).

Yetişkin eğitimi, yetişkinlerin eğitimi için gerekli programların, araç-gereçlerin, yöntemlerin ve tekniklerin geliştirildiği bir eğitim alanıdır (Başaran, 1996). Başka bir ifade ile yetişkin eğitimi; belirli amaçları gerçekleştirmek için yetişkin ve eğiticinin belli bir plan dahilinde yürüttükleri eğitim faaliyetleridir (Uysal, 2004). Yetişkin eğitimi, zorunlu eğitimde tamamlanmamış olan yanların ya da yetersizliklerin yetişkin tarafından daha sonra istekli olarak elde edilmeye çalışılması olarak ifade edilebilir (Oktay, 2001). Yapılan tanımlar ışığında yetişkin eğitimi "yetişkin bireyin örgün eğitim dışında becerilerini artırmak, kendini geliştirmesine olanak sağlamak, meslek sahibi yapmak ve bu faydaların yanında kişinin ruhsal gelişimine, ihtiyaçlarına yanıt vermek için yapılan faaliyetlerin tümü" olarak tanımlanabilmektedir.

Serin'e (1979) göre eğitim istemi, bireylerin belli bir konuyla ilgili olarak örgün ve yaygın eğitim kurumlarına devam edebilme olanağıdır. Alanyazında eğitim istemini belirleyen değişkenlere ilişkin sınıflandırmalar bulunmaktadır (Härnqvist, 1987; Ünal, 1996). Ancak, bu sınıflandırmalar daha çok örgün eğitime devam eden bireyler/genç öğrenenler/çocuklar veya ailesinin eğitim istemi üzerinde belirleyici olan değişkenlerle ilgilidir. Buradan hareketle, genç öğrenenlerle yetişkinlerin eğitim istemlerinin belirleyici olduğu değişkenlerde az ya da çok bir farklılaşma olması kaçınılmazdır. Yapılan bu belirlemeye karşın, yetişkinlerin eğitim istemlerinde belirleyici olduğu düşünülen değişkenlere ilişkin olarak alanyazında herhangi bir sistematik sınıflandırmaya rastlanılmamıştır. Yine de alanyazında bazı çalışmalarda doğrudan olmasa da dolaylı olarak yetişkinlerin eğitim isteminde belirleyici olan değişkenleri görmek mümkündür (Ata, 2016; Boeren, Nicaise ve Baert, 2010; Cilasun, Şeker, Dinçer ve Koru, 2018; Dinçer, Tekin ve Aşkar, 2016; Egglestone, Stevens, Jones ve Aldridge, 2018; Johnstone, 1963; Rubenson, 2007; Türkiye İstatistik Kurumu [TÜİK], 2019).

Cinsiyet, yetişkin bireylerin kendilerine yönelik düzenlenmiş olan eğitim faaliyetlerine (kurs ve eğitim programlarına) yönelik istemlerinde belirleyici değişkenlerden biri olarak öne çıkmaktadır. Avrupa Birliği'nde $(\mathrm{AB})$ kadınların yetişkin eğitim faaliyetlerine katılımı \%10,1 olurken, erkeklerin \%8,6 olduğu gözlenmiştir (Boeren ve diğerleri, 2010). Yine benzer biçimde, Amerika Birleşik Devletleri'nde (ABD) yetişkinlerin eğitim istemlerinde kadınların oranı erkeklerden daha fazladır (Creighton ve Hudson, 2002). Türkiye İstatistik Kurumu'nun (TÜİK, 2019) 2016 verilerine göre, erkeklerin yetişkin eğitim faaliyetlerine katılımları \%19,8 olurken, bu oran kadınlarda ise \%13,8'dir. Türkiye'de kadınların erkeklerle karşılaştırıldığında yetişkin eğitim faaliyetlerine daha az oranda katıldığı görülmektedir. Bunun nedenlerinden biri Türk toplumunun ataerkil yapıya sahip olmasıyla açıklanabilir. Söz konusu bu durum kadınların toplumsal ve ekonomik yaşamda aktif rol almasını sınırlandırmaktadır. Alanyazında yapılan araştırmalar, bireylerin eğitim düzeyi arttıkça yetişkin eğitimine olan istemlerinin de arttığını göstermektedir (Hovdhaugen ve Opheim, 2018; Rubenson, 2007; TÜİK, 2019). Örneğin, TÜİK (2012) verilerine göre, okuryazar olmayan her 100 kadına karşılık 21 erkek okuryazar değildir. Yine, ilköğretim mezunu her 100 kadına karşılık 179 erkek ilköğretim mezunudur. Yine her 100 kadına karşılık 151 erkek lise ve dengi okul mezunu olup yüksekokul mezunu her 100 kadına karşılık 149 erkek yüksekokul mezunudur. Dolayısıyla, bu veriler ile alanyazında yapılan araştırma bulguları değerlendirildiğinde, Türkiye' de kadınların erkeklere göre yetişkin eğitimine daha az istemde bulunmasının bir nedeninin onların eğitim düzeyiyle ilişki olduğu söylenebilir.

Alanyazında yapılan araştırmalar bireylerin kendi gereksinimlerine yönelik eğitim faaliyetlerine 
katılımlarında cinsiyet rollerinin belirleyici olduğunu ortaya koymaktadır (Ata, 2016; Miser, 1987; Tekin, 1988, Ünal, 1996; Yılmaz, 2009; Yolcu, 2011a). Bu doğrultuda, kadınlar daha çok ev içi işleri destekleyici ya da işgücü piyasasında düşük statülü mesleklerle ilişkili eğitimleri, erkeklerin ise işgücü piyasasında yüksek statülü mesleklerle ilişkili eğitimleri seçtikleri gözlenmektedir. Ünal'ın (1996) belirttiği gibi, bütün bunlar bir yandan toplumsal cinsiyet tanımları ve tanımlamaları üzerinden eğitim isteminin biçimlenmesine yol açarken, bir yandan da toplumun istediği yönde cinsiyet rolleri yeniden üretilmiş olmaktadır.

Yaşam süresi evrelerini yansıtan yaş, genellikle yetişkinlerin eğitim istemleri üzerindeki en iyi belirleyicilerden biridir (European Commission, 2019). Bélanger ve Valdiviselo (1997, akt. Rubenson, 2007), daha ileri yaşa sahip olan yetişkinlerin eğitim istemlerinde son yıllarda bir artış olduğunu belirtmektedir. Ancak, bu durum çalışma yaşamını uzatan yasal düzenlemelerle ilgili olduğu kadar, işgücü piyasasındaki yeni nesillerin öncekilerden daha eğitimli olmasıyla da yakından ilgilidir. Bu nedenle ileri yaştaki yetişkinler, işgücü piyasasındaki rekabetçi yapıyla daha iyi başa edebilmek için eğitim faaliyetlerine daha fazla katılmak istemektedir. ABD'de 1960'ta 25-29 yaş grubundaki işçilerin \%60'inda lise diploması varken \%8'inden daha azında ise bir lisans derecesi bulunmaktaydı. Bununla birlikte 1990'a kadar, bu grubun \%84'ü lise diplomasına ve \%22'si de lisans diplomasına sahip olmuştur (Bosworth, 2008). Dolayısıyla, bu durum yeni neslin bir öncekiyle karşılaştırıldığında eğitim faaliyetlerine olan isteminin daha fazla olduğunu göstermektedir. Son araştırmalar, yetişkinlerin eğitime katılmaya hazır olduklarını ve bu yöndeki istemlerinin erken yetişkinlikten 50'li yaşların ortalarına kadar oldukça sabit kaldığını göstermektedir. Bununla birlikte 55 yaş ve üstü yaş grubundaki yetişkinlerin eğitim istemlerinde belirgin bir düşüş gözlenmektedir (Rubenson, 2007). Alanyazında bunu doğrulayan araştırmalar bulunmaktadır (Boeren ve diğerleri, 2010; Creighton ve Hudson, 2002; TÜİK, 2019). Örneğin, AB'de 25-39 yaş arasındaki yetişkinlerin eğitim faaliyetlerine katılımı \%13,4 olurken, bu oran 40-49 yaş grubunda \%8,6 ve 50-64 yaş grubunda \%5,1'dir (Boeren ve diğerleri, 2010). Türkiye' de, 2016 yılında 18-24 yaş arasında olanların eğitim faaliyetlerine katılımı \%26 iken 25-34 yaş arasında olanların \%11,5, 55-64 yaş arasında olanların \%4,4 ve 65 yaş ve üzerinde olanların ise \%2' dir (TÜİK, 2019).

Kişisel özelliklerin en önemli betimleyici değişkenleri arasında yer alan medeni durum, yetişkin bireylerin eğitim istemleri üzerinde belirleyici olabilmektedir. Johnstone'un (1963) ilgili araştırmasında katılımcıların \%83'ü evlidir. Bu oran Ayhan'ın (1988) araştırmasında \%25, Aşır'ın (2011) araştırmasında ise \%94,73'tür. Yetişkin eğitimine katılanlardan medeni durumu evli olanların oransal olarak daha fazla olması, muhtemelen örneklem grubundaki sayısal büyüklük ile ilgilidir. Yoksa, medeni durumun, yetişkinlerin eğitim istemlerinde tek başına belirleyici olması söz konusu değildir. Örneğin, Dinçer ve diğerleri (2016) ilgili araştırmasında, evli olan yetişkinlerin eğitim istemlerinde toplumsal cinsiyet rollerinin belirleyici olduğunu ortaya koymuştur. Söz konusu araştırmaya göre, evli olan yetişkinlerin çocuk sahibi olması, kadınların eğitim istemlerini kayda değer bir biçimde sınırlandırırken, erkekler üzerinde belirleyici bir etkisi yoktur.

Ekonomik ve sosyal konuların giderek küresel düzeyde genişleme eğilimi göstermesine bir yanıt olarak, yetişkin eğitimi işgücünün niteliğini geliştirmede kullanışlı bir araç olarak ortaya çıkmaktadır. Yine, teknoloji de bireylerin sahip olduğu ya da sahip olması gereken eğitsel nitelikler bakımından işgücü piyasasındaki çalışma durumunu belirleme ya da var olan durumu sürdürebilme açısından oldukça önemli olmaktadır (Dinçer ve diğerleri, 2016). Machin ve Vignoles (2004), işgücü piyasasının yüksek nitelikli ve yeni teknolojileri kullanma becerisine sahip bireyleri yüksek oranda istihdam etme eğiliminde olduğunu belirtmektedir.

Bireylerin işgücü piyasasındaki istihdam durumlarına göre, eğitim istemlerinde bir farklılık olması beklenir. Bu farklılıklardan biri işgücü piyasasında fiili çalışanlarla açık işsiz konumunda olanlar arasındadır. Örneğin, TÜİK'in (2019) verileri, işgücü piyasasında aktif çalışanların eğitim isteminde bulunma oranları $\% 20,1$ iken, iş arayanlarınki ise \%27,6 olduğunu göstermektedir. Burada belirtilmesi gerekenlerden biri de işgücü piyasasında aktif çalışan yetişkinlerin istihdam türünün tam ve yarı zamanlı olması durumunun onların eğitim istemleri üzerinde belirleyici olmasıdır. Ancak, alanyazında yapılan araştırmaların bu konuda farklı bulgular içerdiğini belirtmek gerekmektedir. Buna göre, ABD'de tam zamanlı bir işte çalışanların yarızamanlı ve işsiz olanlara göre yetişkin eğitimine katılımlarının daha fazla olduğu görülmektedir (Creighton ve Hudson, 2002). ABD'nin aksine, İngiltere'de ve Türkiye'de tam ve yarı zamanlı çalışanların eğitim programlarına dahil olmalarında belirgin fark yoktur (Dinçer ve diğerler, 2016; Egglestone ve diğerleri, 2018). 
Mesleksel statünün/konumun yetişkin bireylerin eğitime yönelik istemleri üzerinde belirleyici olduğu görülmektedir. ABD'de yüksek statülü meslek grubuna dahil olan yetişkinlerin daha alt düzeydeki meslek gruplarına dahil olanlarla karşılaştırıldığında, yetişkin eğitimine yönelik istemlerinin daha fazla olduğu görülmektedir. Buna göre, en fazla katılım profesyonel ve yönetim meslek gruplarında olurken, en az katılım ise ticaret meslek gruplarında olmaktadır (Creighton ve Hudson, 2002). Bununla birlikte, yetişkin bireylerin eğitim istemlerinin çalışmış olduğu sektörle de ilişkili olduğu görülmektedir. Örneğin, Türkiye'de 2003-2006 yılları arasında otomotiv sektöründeki büyümeye paralel olarak, sektör çalışanlarının yetişkin eğitimine katılımlarında bir artış gözlenmiştir. Yine, belirtilen yıllar arasında tekstil sektöründeki daralma ise bu sektörde çalışanların eğitimine katılımlarını düşürmüştür (Dinçer ve diğerleri, 2016).

İnsan Sermayesi Kuramına (İSK, Human Capital Theory) göre, bireyler yüksek getiri sağlayan eğitim programlarına daha fazla istemde bulunurlar. Buna göre, herhangi bir eğitim programına istemde bulunan bireylerin, bu yöndeki istemlerinin arkasında belli bir gelir beklentisinden söz etmek mümkündür (Ünal, 1996). Bu doğrultuda bireyler, getirisi yüksek olan eğitimlere daha fazla harcama yapmaya daha istekli olabilmektedir. Ancak, yetişkin bireyler eğitimin kamu tarafından sunulması durumunda bu eğitim faaliyetlerine daha fazla istemde bulunurken, kendileri finans etmek veya finansmanına kismen katılmak durumunda kaldıklarında ise bu istemlerinde bir düşüş gözlenmektedir (Cilasun ve diğerleri, 2018; Hovdhaugen ve Opheim, 2018).

Alanyazında yapılan araştırmalar eğitim düzeyi ile yetişkin eğitimine olan istem arasında doğrusal yönde pozitif bir ilişki olduğunu ortaya koymaktadır. Örneğin, $A B^{\prime}$ de eğitim düzeyi yüksek yetişkinlerin eğitim düzeyi düşük olan yetişkinlere göre eğitim faaliyetlerine katılımı yedi kat daha fazladır (Boeren ve diğerleri, 2010). Yine, Onchari'nin (2016) araştırmasında, yetişkin eğitimine katılan bireylerin çoğunun lise mezunu olduğu gözlenmiştir. Türkiye'de lise ve yükseköğretim mezunu olan yetişkinler daha alt öğrenim düzeyine sahip bireylere göre yetişkin eğitim faaliyetlerine olan eğitim istemleri daha fazladır (Cilasun ve diğerleri, 2018; Dinçer ve diğerleri, 2016; TÜIKK, 2019).

Ailelerin gelir düzeyi bireylerin eğitim istemi kararları üzerinde belirleyici olan diğer değişkenlerden birini oluşturmaktadır (Ünal, 1996; Yolcu, 2011b). Burada beklenilen ailelerin gelir düzeyi artıkça yetişkin eğitim faaliyetlerine olan istemde bir artış olmasıdır. Aksi durumda, gelir düzeyinin düşmesi veya işgücü piyasasının dışında kalınması durumunda da yine, gelir düzeyiyle ilişkili olarak bir azalma olmasıdır (Balami ve Sakir, 2014; Holt ve Smith, 2005). Örneğin, Kim, Collins, Williamson ve Chapman'ın (2004) 2001 yılı Ulusal Hanehalkı Eğitim Araştırması'nda (National Household Education Surveys of 2001), araştırmaya katılanlar arasında en düşük gelir grubunda (20.000 \$ ve altı) olanların yetişkin eğitimlerine katılım oranı \%20 iken, bu oran en üst grupta (75.000 \$ ve üstü) olanlarda ise $\% 23^{\prime}$ tür.

Yetişkin eğitimi, yetişkinlere eğitim sistemlerine yeniden erişme veya yeni eğitim becerileri ve bilgisini yeniden öğretme fırsatı sunan, 'ikinci şans' olarak tanımlanmaktadır (Grummell, 2007). Bu doğrultuda, yetişkinler için gerçekleştirilen eğitimlerin onların ekonomik, toplumsal ya da kültürel yoksunluklarını giderici içeriğe sahip olması gerekmektedir. Türkiye' de gerek örgün eğitim almış yetişkinlerin gerekse örgün eğitim sürecinden geçmemiş ya da örgün eğitimin dışına çıkmış yetişkinlerin, eğitim gereksinimlerini karşılamak için planlı ve örgütlü eğitim-öğretim faaliyetlerinin yürütüldüğü görülmektedir. Eğitim yoksunluğuna sahip olan insanlar açısından bu faaliyetler, hayatlarını değiştirme açsısından önemlidir (Geray, 2002). Bu noktada yetişkin eğitimi kapsamında yürütülen faaliyetler, kültürel ve ekonomik eğitim yoksunluğuna sahip yetişkinlerin eğitimleri ile ilgili eksiklikleri büyük oranda kapatabilmektedir (Okçabol, 1996). Halk Eğitim Merkezleri (HEM), Türkiye'de öteden beri yetişkin eğitim faaliyetlerinin yürütüldüğü kurumlardan biridir. TÜİK (2017) verilerine göre, Türkiye genelinde bulunan HEM'lerin sayısı 969'dur. Yine TÜİK verilerine göre, 2011 yılında HEM'lere devam edenlerin sayıs1 3. 977.650'dur.

Türkiye'de alanyazında, yetişkin eğitimini ele alan araştırmalar da bulunmaktadır (Ata, 2016; Ayhan, 1990; Ecevit, 2003; Hablemitoğlu, 2005; Miser, 1999; Oğuzkan ve Okçabol, 1993; Tekin 1991, 1988; Tezcan ve Duman, 2014; Ural, 1995, 2007; Uysal, 2005; Vatandaş, 2007; Yıldırım, 2009; Yıldız, 2006). Bu araştırmalar; HEM ve halk eğitimcilerini (Tekin, 1991; Yıldırım, 2009), okuryazarlık konusunu (Tezcan ve Duman, 2014; 
Yıldız, 2006), toplum kalkınmasını (Ecevit, 2003; Hablemitoğlu, 2005; Miser, 1999; Ural, 2007; Vatandaş, 2007), katılım konusunu (Ata, 2016; Ayhan, 1990; Tekin, 1988; Ural, 1995) ve yetişkin öğrenmesini (Oğuzkan ve Okçabol, 1993; Uysal, 2005) ele almıştır. Yine, alanyazında eğitim istemini konu alan araştırmalara da rastlamak mümkündür (Aksan, 1989; Altunsaray, 2000; Aslan, 2014; Barutçu, 1996; Bingöl, 2004; Kurnaz, 1996; Mutaf, 1995; Özbaran, 2016; Sarpkaya, 2010; Tansel, 2002; Yolcu, 2011a). Alanyazında eğitim istemini konu alan bu araştırmalardan Kurnaz'ın (1996) araştırması dışarıda bırakıldığında, diğer araştırmalar örgün eğitim içindeki öğrencilerin eğitim istemini konu edinmiştir. Kurnaz (1996), ilgili araştırmasında açık yükseköğretime olan eğitim istemini irdelemiştir. Alanyazında, gerek eğitimi istemini gerek yetişkin eğitimini konu alan bu araştırmalar birlikte ele alındığında doğrudan yetişkinlerin eğitim istemlerini konu edinmediği görülmektedir. Dolayısıyla, bu araştırma diğer araştırmalardan farklı olarak eğitimin ekonomik boyutuyla ilişkili olması yönüyle bir anlamda alanyazındaki eksik kalan bir boyutu tamamlar niteliktedir. Bunun dışında ortaya koyacağı bulgularla konu ile ilgili yeni çalışmalara ışık tutacağı düşünülmektedir.

$\mathrm{Bu}$ araştırmanın genel amacı, Ankara ilinde bulunan HEM'lerdeki eğitim faaliyetlerine devam eden yetişkinlerin eğitim istemlerinin boyutlarını ve bu istemleri üzerinde belirleyici olan değişkenleri ortaya koymaktadır. Yalnız burada belirtilmesi gereken, HEM'lerdeki eğitim faaliyetlerine, örgün eğitime devam eden, örgün eğitime hiç dahil olmamış ve örgün eğitimden tamamen çıkmış kişilerin devam ettiğidir. Söz konusu bu durum, göz önünde bulundurularak araştırmaya örgün eğitimden tamamen çıkmış 25 yaş ve üzerindeki kişiler dahil edilmiştir. Dolayısıyla, araştırmanın yukarıda belirtilen genel amacı ve sınırlılığı bağlamında, bu araştırmada aşağıdaki sorulara yanıt aranmıştır:

1. HEM'lerdeki faaliyetlere katılan yetişkinlerin eğitim istem düzeyleri nedir?

2. HEM'lerdeki eğitim faaliyetlerine katılan yetişkinlerin sosyo-demografik değişkenlere (cinsiyet, yaş, medeni durum, öğrenim düzeyi, meslek durumu, çalışma durumu, aylık gelir ve hanedeki kişi sayısı) göre eğitim istemleri anlamlı olarak farklılaşmakta mıdır?

\section{Yöntem}

$\mathrm{Bu}$ başlık altında; araştırma modeli, çalışma grubu, veri toplama aracı, verilerin elde edilmesi ve çözümlenmesine ilişkin bilgi verilmiştir.

\section{Araştırma Modeli}

HEM'lerdeki eğitim faaliyetlerine katılan yetişkinlerin eğitim istemlerinin ortaya konulmasını amaçlayan bu araştırma, tarama modelinde açıklayıcı bir araştırmadır. Bir konu veya bir olayla ilgili olarak katılımcıların görüşleri, ilgi, yetenek, tutum gibi niteliklerinin tespit edildiği genellikle diğer araştırmalara göre daha geniş örneklemler üzerinde uygulanan araştırmalara, tarama araştırmaları denilmektedir (Büyüköztürk, Çakmak, Aygün, Karadeniz ve Demirel, 2013). Bir araştırmanın tarama modeli olabilmesinin birkaç ön koşulu bulunmaktadır. Bunlardan ilki, araştırmanın büyük bir topluluğun bir konuyla ilgili görüşlerinin betimlenmesi için uygun büyüklükte bir örneklem seçilmesidir. İkinci, araştırma verilerinin; anket formu, gözlem çizelgesi ya da görüşme yönergesi vb. standart bir veri toplama aracıyla katılımcılardan sistemli bir biçimde toplanmasıdır. Üçüncüsü ise araştırma sürecinde elde edilen verilerin istatistiksel olarak çözümlenebilmesidir (De Vaus, 1990, akt. Şavran, 2012; Fraenkel ve Wallen, 2011). Buna göre, yetişkinlerin HEM'lerdeki eğitim faaliyetlerine olan istemlerini ortaya koymayı amaçlayan bu araştırma; çalışma gurundaki katılımcıların sayısının yanı sıra, verilerin standart bir veri toplama aracıyla toplanması ve elde edilen verilerinde istatiksel olarak çözümlenmesi nedeniyle, tarama modelinde bir araştırma niteliğindedir.

\section{Çalışma Grubu}

Araştırmanın çalışma grubu 2018-2019 eğitim-öğretim yılında Ankara Büyükşehir Belediyesi sınırları içinde bulunan ilçelerdeki HEM'lerde eğitim faaliyetlerine katılan yetişkinlerdir. Ancak, bu ilçelerdeki HEM'lere katılan yetişkinlerin sayısını tam olarak belirlemek mümkün olmamıştır. Bu nedenle, araştırmanın çalışma evreni içinde bulunan Mamak, Altındağ, Keçiören, Yenimahalle ve Çankaya ilçelerindeki HEM’lerde eğitim faaliyetlerine katılan yetişkinlerden gönüllülük esasına dayalı olarak bir çalışma grubu 
oluşturulmuştur. Söz konusu ilçelerin çalışma grubuna dahil edilmesinde zaman, ulaşılabilirlik ve maliyet gibi unsurlar göz önünde bulundurulmuştur.

Araştırmanın çalışma grubu kolay örnekleme ile seçilen yetişkinlerden oluşmaktadır. Bu yöntemde araştırmaya katılmak isteyen bireylerin tümünün örnekleme katılması amaçlanmaktadır. Kolay örnekleme yöntemi araştırmacıya zaman, para ve işgücü kayıpları bakımından tasarruf sağlayan bir yöntem olarak bilinmektedir (Büyüköztürk ve diğerleri, 2013; Ural ve Kılıç, 2011). Söz konusu bu yöntem, araştırmacıya belirtilen konularda bir avantaj sağlasa da seçkisizlik sağlamadığından dolayı elde edilen sonuçların evrene genellenmesi söz konusu değildir (Creswell, 2012; Büyüköztürk ve diğerleri, 2013; Fraenkel ve Wallen, 2011). Araştırmanın çalışma grubunda bulunanların yetişkinlerin cinsiyet, yaş, medeni durum, öğrenim düzeyi, meslek durumu, çalışma durumu, aylık gelir ve hanedeki kişi sayılarına ilişkin bilgiler Tablo 1'de yer verilmiştir.

Tablo I

Katılımcıların Demografik Özellikleri

\begin{tabular}{|c|c|c|c|}
\hline Değişken & & $\mathrm{f}$ & $\%$ \\
\hline \multirow{2}{*}{ Cinsiyet } & Kadın & 187 & 75,7 \\
\hline & Erkek & 60 & 24,3 \\
\hline \multirow{2}{*}{ Medeni Durum } & Evli & 193 & 78,1 \\
\hline & Bekar & 54 & 21,9 \\
\hline \multirow{6}{*}{ Öğrenim Düzeyi } & Okuma yazma biliyor ancak bir okul bitirmemiş & 12 & 4,9 \\
\hline & İlkokul & 53 & 21,5 \\
\hline & Ortaokul & 36 & 14,6 \\
\hline & Lise & 57 & 23,1 \\
\hline & Üniversite & 83 & 33,6 \\
\hline & Lisansüstü & 6 & 2,4 \\
\hline \multirow{8}{*}{ Meslek } & Memur/Memur Emeklisi & 44 & 17,8 \\
\hline & İşçi/İşçi Emeklisi & 40 & 16,2 \\
\hline & Çiftçi & 2 & 8 \\
\hline & Serbest meslek & 15 & 6,1 \\
\hline & Esnaf/Tüccar & 2 & 8 \\
\hline & İşsiz & 14 & 5,7 \\
\hline & Ev kadını & 117 & 47,4 \\
\hline & Diğer & 13 & 5,3 \\
\hline \multirow{6}{*}{ Çalışma Durumu } & Özel Sektör & 46 & 18,6 \\
\hline & Kamu (Daimî Kadrolu) & 44 & 17,8 \\
\hline & Kamu (Sözleşmeli) & 5 & 2,0 \\
\hline & Kamu (Geçici işçi) & 3 & 1,2 \\
\hline & Çalışmiyor & 117 & 47,4 \\
\hline & İşsiz & 32 & 13,0 \\
\hline \multirow{4}{*}{ Yaş } & $25-34$ & 54 & 21,9 \\
\hline & $35-54$ & 136 & 55,1 \\
\hline & $55-64$ & 40 & 16,2 \\
\hline & $65+$ & 17 & 6,9 \\
\hline \multirow{7}{*}{ Hanedeki Birey Sayısı } & 1 & 17 & 6,9 \\
\hline & 2 & 39 & 15,8 \\
\hline & 3 & 63 & 25,5 \\
\hline & 4 & 69 & 27,9 \\
\hline & 5 & 37 & 15,0 \\
\hline & 6 & 9 & 3,6 \\
\hline & 7 ve üzeri & 13 & 5,3 \\
\hline \multirow{5}{*}{ Aylık Gelir } & $1500 \mathrm{TL}^{*}$ ve altı & 35 & 14,2 \\
\hline & 1501-2000 TL & 71 & 28,7 \\
\hline & $2001-3000 \mathrm{TL}$ & 57 & 23,1 \\
\hline & $3501-4000 \mathrm{TL}$ & 37 & 15,0 \\
\hline & 5000 TL ve üzeri & 47 & 19,0 \\
\hline
\end{tabular}


Tablo 1'deki verilere göre, yetişkinlerin demografik verilerinin dağılımına göz atıldığında araştırmaya katılanların \%75,7'si kadın, \%24,3'ü erkeklerden oluşmaktadır. Araştırmaya katılanların \%78,1'i evli, \%21,9'u ise bekardır. Yine, araştırmaya katılanların $\% 4,9^{\prime} \mathrm{u}$ okuma yazma biliyor ancak bir okul bitirmemiş, \%21,5'i ilkokul, \%14,6'sı ortaokul, \%23,1'i lise, \%33,6'sı üniversite ve \%2,4'ü lisansüstü mezunudur. Meslek durumları bakımından araştırmaya katılanların dağılımına bakıldığında \%17,8'i memur/memur emeklisi, \%16,2'si iş̧̧i/işçi emeklisi, \%0,8'i çiftçi, \%6,1'i serbest meslek, \%0,8'i esnaf/tüccar, \%5,7'si işsiz, \%42,4'ü ev kadını, \%5,3'ü diğer meslek gruplarına dahildir. Araştırmaya katılanların çalışma durumları incelendiğinde \%18,6'sı özel sektör, \%17,8'i kamu (daimî kadrolu), \%2'si kamu (sözleşmeli), \%1,2'si kamu (geçici işçi), \%47,4'ü çalışmıyor, \%13'ü işsiz durumdadır.

Yine, Tablo 1'deki veriler üzerinden devam edildiğinde, araştırmaya katılanların \%21,9'u 25-34 yaş aralığında, \%55,1'i 35-54 yaş aralığında, \%16,2'si 55-64 yaş aralığında ve \%6,9'u 65 yaş üstündedir. Diğer yandan, katılımcıların \%6,9'u bir kişiden oluşan bir hanede yaşarken, \%15,8'i 2, \%25,5' i 3, \%27,9' u 4, \%15'inin hanesinde beş kişi, \%3,6'sının altı kişi, \%5,3'ünün yedi kişi ve üzerinde oluşan hanede yaşamakta olduğu gözlenmektedir. Bunlara ek olarak, katılımcıların \%14,2'si 1500 TL ve altında bir gelire sahip iken, \%28,7'si 1501-2000 TL arasında, \%23,1'i 2001-3000 TL arasında, \%15'i 3501-4000 TL arasında, \%19'u 5000 TL ve üzerinde aylik bir gelire sahiptir.

\section{Veri toplama Araçları}

Araştırmada iki farklı veri toplama aracı kullanılmıştır. Bunlardan ilki araştırmaya katılan katılımcıların sosyo-demografik özelliklerine ilişkin bilgileri içeren "Kişisel Bilgi Formu"dur. Bu kısımda katılımcıların cinsiyeti, medeni durumu, öğrenim düzeyi, mesleki durumu, çalışma durumuna ve yaşına yönelik soruların yanı sıra hanedeki birey sayısı ve aylık gelir durumlarına ilişkin kapalı uçlu sorulara yer verilmiştir.

Araştırmada kullanılan ikinci veri toplama aracı ise Yolcu ve Aktaş'ın (2018) geliştirmiş olduğu “Halk Eğitim Merkezlerinde Yürütülen Eğitim Programlarına Katılan Yetişkinlerin Toplumsal Cinsiyet Bağlamında Eğitim İstemlerinin Değerlendirilmesi Ölçeği" kullanılmıştır. Ölçme araçlarına ilişkin ayrıntılı bilgilere aşağıda yer verilmiştir. Yolcu ve Aktaş (2018) yetişkinlerin toplumsal cinsiyet bağlamında eğitim talebini ölçebilmek için bu ölçeği geliştirmiştir. Ölçek Sinop il merkezi, Boyabat ve Ayancık ilçesinde bulunan üç halk eğitim merkezinde, araştırma kriterlerine uyan ve araştırmaya katılmayı kabul eden 158 yetişkin üzerinde gerçekleştirilmiştir. Verilerin toplanmasında araştırmacılar tarafından geliştirilen taslak ölçek kullanılmıştır. Verilerin analizinde tanımlayıcı istatistikler, yapı geçerliliği için açımlayıcı faktör analizi yapılmıştır. Güvenirlik analizi için Cronbach Alpha testi kullanılmıştır. Yapılan güvenirlik analizi sonucunda, ölçeğin Cronbach's alfa katsayısı 0,88 olarak hesaplanmıştır. 5'li likert tipi olan ölçek, 20 maddeden oluşmaktadır. "Sosyal”, “Mesleki”, “Kendini Geliştirmek”, “Ekonomik”, “Kişisel” olmak üzere 5 alt boyuttan oluşmaktadır.

Ölçeğin birinci alt boyutu, Sosyal alt boyutudur. Bu alt boyutta "Yeni şeyler öğrenmek", "Çevresindekilere daha faydalı olmak", "Ev dışında faaliyetlerde bulunmak", "Boş zamanları değerlendirmek", "Yeni insanlarla tanışmak", "Arkadaşlarla ortak bir faaliyet içinde bulunmak" olmak üzere altı madde bulunmaktadır. Ölçeğin bu alt boyutundaki maddelerin madde yük değerleri 0,535 ile 0,770 arasında değişmektedir. İkinci alt boyut, Mesleki alt boyuttur. Bu boyutta "Mesleki konuda kendini geliştirmek", "Meslek edinmek", "İş yeri açmak", "İş başvurularında kullanmak için belge (sertifika) almak" olmak üzere dört madde bulunmaktadır. Ölçeğin bu alt boyutundaki maddelerin madde yük değerleri 0,559 ile 0,839 arasında değişmektedir. Üçüncü alt boyut, Kendini Geliştirmek alt boyutudur. Bu boyutta "Dil öğrenmek", "Sınavlara hazırlanmak", "Özgüven kazanmak", "Eğitim eksikliğini kapatmak" olmak üzere dört madde bulunmaktadır. Ölçeğin bu alt boyutundaki maddelerin madde yük değerleri 0,527 ile 0,835 arasında değişmektedir. Dördüncü alt boyut, Ekonomik alt boyuttur. Bu boyutta "Kursiyerlere verilen ekonomik destekten yararlanmak", "Maddi kazanç elde etmek", "Çeyizlik ürünleri ucuza mal etmek" olmak üzere üç madde bulunmaktadır. Ölçeğin bu alt boyutundaki maddelerin madde yük değerleri 0,426 ile 0,804 arasında değişmektedir. Beşinci alt boyut Kişisel alt boyuttur. Bu boyutta "Ev ortamından uzaklaşmak", "İçinde bulunulan sıkıntıdan kurtulmak", "Toplumda kabul görmek" olmak üzere üç madde bulunmaktadır. Ölçeğin bu alt boyutundaki maddelerin madde yük değerleri 0,539 ile 0,802 arasında değişmektedir. 


\section{Verilerin Toplanması}

Araştırmanın veri toplama aracının uygulanması için ilk önce Milli Eğitim Bakanlığı Yenilik ve Eğitim Teknolojileri Genel Müdürlüğü'ne 06/01/2019 tarihinde "ayse.meb.gov.tr" üzerinden başvuru yapılmıştır. Buradan alınan belgelerle Kastamonu Üniversitesi Sosyal Bilimler Enstitüsü aracılığıyla Ankara İl Milli Eğitim Müdürlüğ̈̈'ne dilekçe ile başvurulmuştur. Yapılan bu yazışmalar sonuncunda Ankara İl Milli Eğitim Müdürlüğ̈̈'nden 05/02/2019 tarihinde araştırmanın veri toplama aracının uygulama izni alınmıştır. Bunun üzerine alana çıkılarak veri toplama aracının uygulanmasına başlanılmıştır.

Veri toplam aracı araştırmanın çalışma gurubunda bulunan ilçelerdeki HEM'ler ziyaret edilerek uygulanmıştır. Araştırmacı bu süreçte, ilk önce kendisini tanıtmış ve araştırmanın amacını açıklanmıştır. Bunun ardından istekli ve gönüllü olanlara veri toplama aracı verilerek uygulanması sağlanmıştır. Ancak, uygulama sırasında bazı kursiyerler uygulamaya katılmak istememiştir. Söz konusu bu durum üzerine araştırmacı, çalışmanın gönüllülük esasına bağlı olarak yapıldığı ve isimlerinin çalışmada olmayacağı tekrar hatırlatılarak, bu kişileri araştırmaya katılmaya motive etmiştir.

\section{Verilerin Analizi}

Araştırmada elde edilen veriler SPSS 23 programı kullanılmıştır. Veri setinde kayıp değer incelemesi yapıldığında herhangi bir veri eksiği saptanmamıştır. Araştırmaya katılanların sosyo-demografik özelliklerine ilişkin veriler betimsel istatistiklerden yararlanılarak çözümlenmiştir. Elde edilen bütün sonuçlar p<,05 düzeyinde test edilmiştir. Veriler normal dağılıma uygunluğu Tek Örneklem Kolmogorov Smirnov Testi kullanılarak belirlenmiştir. Sonuçların Cronbach Alfa değeri 0,89 olarak bulunmuştur. Bu değer ölçeğin güvenilir olduğunu göstermektedir. Alanyazında, alfa katsayısının 0,80-1,00 arasında olması, ölçeğin yüksek güvenirliğe sahip olduğunu göstermektedir (Büyüköztürk, 2010). Ölçekten alınan veriler çeşitli değişkenler açısından karşılaştııılmıştır. Burada yüzde, frekans, ortalama ve standart sapma gibi tanımlayıcı istatistiklerin yanı sıra veriler normal dağılım gösterdiğinden iki grubun arasındaki farkın anlamlı olup olmadığını ölçmek için $\mathrm{T}$ Testi kullanılırken, ikiden fazla grubun ortalamalarının karşılaştırılması için ANOVA testi kullanılmıştır. Farklılaşmanın hangi gruplar arasında olduğunu bulmak için Tukey HSD testinden yararlanılmıştır.

\section{Bulgular}

Bu bölümde araştırmaya katılan yetişkinlerin, HEM'lerdeki eğitim faaliyetlerine olan istem düzeylerinin yanı sıra, bu istemlerinin sosyo-demografik değişkenlere (cinsiyet, yaş, medeni durum, öğrenim düzeyi, meslek durumu, çalışma durumu, aylık gelir ve hanedeki birey sayısı) göre farklılaşma durumunu ortaya koymaya yönelik elde edilen bulgular, aşağıda sırasıyla ele alınmıştır.

Tablo 2'de araştırmaya katılım gösteren yetişkinlerin, ölçeğin alt boyutlarına katılım düzeylerine ilişkin, aritmetik ortalama ve standart sapma puanlarına yönelik bilgiler yer almaktadır.

\section{Tablo II}

Katılımcıların Ölçeğin Alt Boyutlarına İlişkin Katılım Düzeyleri

\begin{tabular}{llcc}
\hline Alt Boyut & $\mathbf{N}$ & $\bar{x}$ & ss \\
\hline Sosyal & & 247 & 3,46 \\
Kişisel & 247 & 2,64 & 1,21 \\
Mesleki & 247 & 2,48 & 1,19 \\
Kendini Geliştirmek & 247 & 2,45 \\
Ekonomik & 247 & 1,16 \\
\cline { 2 - 4 }
\end{tabular}

Tablo 2'deki bilgilere göre, katılımcıların ölçeğin alt boyutlardan en fazla "Sosyal" ( $\bar{x}=3,46$, ss=,94) alt boyuta katılım gösterdikleri gözlenmektedir. Ölçeğin bu boyutunu sırasıyla "Kişisel" $(\bar{x}=2,64, \mathrm{ss}=1,21)$, "Mesleki" ( $\bar{x}=2,48, \mathrm{ss}=1,19)$ ve "Kendini Geliştirmek" $(\bar{x}=2,45, \mathrm{ss}=1,16)$ alt boyutları izlemektedir. Diğer yandan, HEM'lerdeki eğitim faaliyetlerine istemde bulunan yetişkinlerin, ölçeğin alt boyutları arasında en az katılım gösterdikleri boyut ise "Ekonomik" ( $\bar{x}=2,35$, ss=1,24) alt boyuttur. 
Tablo 3'te katılımcıların ölçeğin her bir maddesine katılım düzeylerine ilişkin bulgulara yer verilmiştir.

\section{Tablo III}

Katılımcların Ölçeğin Her Bir Maddesine Katılım Düzeylerine Göre Dağılımları

\begin{tabular}{|c|c|c|c|}
\hline Madde & $\mathbf{N}$ & $\bar{x}$ & ss \\
\hline Yeni şeyler öğrenmek & 247 & 3,87 & 1,18 \\
\hline Çevresindekilere daha faydalı olmak & 247 & 3,60 & 1,21 \\
\hline Boş zamanları değerlendirmek & 247 & 3,47 & 1,33 \\
\hline Ev dişında faaliyetlerde bulunmak & 247 & 3,37 & 1,31 \\
\hline Arkadaşlarla ortak bir faaliyet içinde bulunmak & 247 & 3,21 & 1,30 \\
\hline Yeni insanlarla tanışmak & 247 & 3,21 & 1,28 \\
\hline Mesleki konuda kendini geliştirmek & 247 & 3,10 & 1,52 \\
\hline Özgüven kazanmak & 247 & 2,80 & 1,52 \\
\hline Eğitim eksikliğini kapatmak & 247 & 2,78 & 1,55 \\
\hline İçinde bulunulan sıkıntıdan kurtulmak & 247 & 2,78 & 1,48 \\
\hline Toplumda kabul görmek & 247 & 2,63 & 1,56 \\
\hline Meslek edinmek & 247 & 2,62 & 1,58 \\
\hline Maddi kazanç elde etmek & 247 & 2,62 & 1,59 \\
\hline Ev ortamından uzaklaşmak & 247 & 2,51 & 1,48 \\
\hline İş başvurularında kullanmak için belge (sertifika) almak & 247 & 2,37 & 1,57 \\
\hline Kursiyerlere verilen ekonomik destekten yararlanmak & 247 & 2,34 & 1,54 \\
\hline Dil öğrenmek & 247 & 2,31 & 1,58 \\
\hline Çeyizlik ürünleri ucuza mal etmek & 247 & 2,08 & 1,47 \\
\hline Sinavlara hazırlanmak & 247 & 1,90 & 1,43 \\
\hline İş yeri açmak & 247 & 1,82 & 1,23 \\
\hline
\end{tabular}

Tablo 3'teki veriler incelendiğinde, katılımcıların en fazla katılım gösterilen madde "Yeni şeyler öğrenmek" $(\bar{x}=3,87, \mathrm{ss}=1,18)$ iken, bunu "Çevresindekilere daha faydalı olmak" $(\bar{x}=3,60$, ss=1,21), "Boş zamanları değerlendirmek" ( $\bar{x}=3,47, \mathrm{ss}=1,33)$ maddeleri izlemektedir. Yine, Tablo 3'te görüleceği gibi en az katılım gösterilen madde "İş yeri açmak" $(\bar{x}=1,82, \mathrm{ss}=1,23)$ olup bunu "Sınavlara hazırlanmak" ( $\bar{x}=1,90$, ss $=1,43)$ ve "Çeyizlik ürünlerini ucuza mal etmek" ( $\bar{x}=2,08$, ss $=1,47)$ maddeleri izlemektedir. Bu veriler, yetişkinlerin daha çok yeni bir şeyler öğrenmek amacıyla, HEM"lerdeki eğitim faaliyetlerine istemde bulunduklarını göstermektedir.

HEM'lere devam eden yetişkinlerin, cinsiyet değişkenine göre eğitim istemlerine ilişkin $t$ testi sonuçları Tablo 4 'te verilmiştir.

\section{Tablo IV}

Katılımcıların Cinsiyetlerine Göre Ĕ̆gitim İstemlerine İlişkin T Testi Sonuçları

\begin{tabular}{lcccccc}
\hline Boyut & Cinsiyet & $\mathbf{N}$ & $\bar{x}$ & ss & \multirow{2}{*}{$\mathbf{p}^{*}$} & \multirow{2}{*}{$040^{*}$} \\
\hline \multirow{2}{*}{ Ekonomik } & Kadın & 187 & 2,43 & 1,24 & \multirow{2}{*}{2,08} & 1,06 \\
& Erkek & 60 & 2,08 & & \\
\hline
\end{tabular}

${ }^{* \mathrm{p}<0,05}$

Tablo 4'te yer alan verilere göre, katılımcıların cinsiyeti ile eğitim eğitimleri arasında, ölçeğin "Sosyal" "Mesleki", "Kendini Geliştirmek" "Kişisel" alt boyutlarına göre, anlamlı farklılık bulunmaz iken "Ekonomik" $\left[\mathrm{t}_{(245)}=2,08 ; \mathrm{p}<0,40\right]$ alt boyutu bakımından anlamlı fark bulunmaktadır. Buna göre araştırmaya katılan Kadın katılımcılar $(\bar{x}=2,43)$, Erkek $(\bar{x}=2,08)$ katılımcılarla karşılaştırıldığında, HEM"lerdeki eğitim faaliyetlerine ekonomik nedenlerle daha fazla istemde bulunmaktadır.

Katılımcıların yaşlarına göre eğitim istemlerini ortaya koymaya yönelik ANOVA testi sonuçları Tablo 5 'te verilmiştir.

Tablo V

Katılımcıların Yaşlarına Göre Ĕ̆itim İstemlerine İlişkin ANOVA Testi Sonuçları

\begin{tabular}{|c|c|c|c|c|c|c|c|}
\hline Boyut & Yaş & $\mathbf{N}$ & $\bar{x}$ & ss & F & $\mathrm{p}^{*}$ & $\overline{\text { Anlamlı Fark (Tukey HSD) }}$ \\
\hline & $25-34(1)$ & 54 & 2,80 & 1,08 & \multirow{2}{*}{7,61} & \multirow{2}{*}{, $000^{*}$} & $1-3$ \\
\hline Mesleki & $35-54$ (2) & 136 & 2,61 & 1,23 & & & $1-4$ \\
\hline
\end{tabular}




\begin{tabular}{|c|c|c|c|c|c|c|c|}
\hline & $55-64(3)$ & 40 & 1,91 & 0,97 & & & $2-3$ \\
\hline & $65+(4)$ & 17 & 1,74 & 1,02 & & & $2-4$ \\
\hline & Toplam & 247 & 2,48 & 1,19 & & & \\
\hline \multirow{5}{*}{ Kendini Geliştirmek } & $25-34(1)$ & 54 & 2,73 & 1,20 & \multirow{5}{*}{3,44} & \multirow{5}{*}{, $018^{*}$} & \multirow{5}{*}{$1-4$} \\
\hline & $35-54(2)$ & 136 & 2,47 & 1,18 & & & \\
\hline & $55-64(3)$ & 40 & 2,30 & 1,03 & & & \\
\hline & $65+(4)$ & 17 & 1,75 & 0,89 & & & \\
\hline & Toplam & 247 & 2,45 & 1,16 & & & \\
\hline \multirow{5}{*}{ Ekonomik } & $25-34(1)$ & 54 & 2,20 & 1,08 & \multirow{5}{*}{5,58} & \multirow{5}{*}{, $002^{*}$} & \multirow{5}{*}{$2-4$} \\
\hline & $35-54(2)$ & 136 & 2,58 & 1,30 & & & \\
\hline & $55-64(3)$ & 40 & 2,15 & 1,16 & & & \\
\hline & $4.65+(4)$ & 17 & 1,43 & 0,81 & & & \\
\hline & Toplam & 247 & 2,35 & 1,24 & & & \\
\hline
\end{tabular}

Tablo 5'teki analiz sonuçlarına göre, ölçeğin "Mesleki" [F(3-243) =7,61, p<0,01], "Kendini geliştirmek" [F(3243)=3,44; $\mathrm{p}<0,05]$, "Ekonomik" [F(3-243)=5,58; $\mathrm{p}<0,05]$ alt boyutlarında katılımcıların yaşları ve eğitim istemleri arasında istatistiksel olarak anlamlı bir farklılık bulunmaktadır. Ancak, "Sosyal" ve "Kişisel" alt boyutları bakımından anlamlı bir farklılık göstermemektedir. Farklılı̆̆ın hangi gruplar arasında olduğunu belirlemek amacıyla Post Hoc testlerinden Tukey HSD testi yapılmıştır. Buna göre ölçeğin "Mesleki" alt boyutunda 25-34 yaş $(\bar{x}=2,80)$ ile 55-64 yaş $(\bar{x}=1,91)$ arasında olan katılımclların, 65 yaş ve üstünde $(\bar{x}=1,74)$ olan katılımcilardan; 35-54 yaş ( $\bar{x}=2,61)$ ile 55-64 yaş $(\bar{x}=1,91)$ arasında olan katılımcıların, 65 yaş üstü $(\bar{x}$ $=1,74$ ) olan katılımcılardan mesleki nedenlerle, HEM'lerdeki eğitim faaliyetlerine istemde bulunmaları daha fazladır. Bu veriler, yaşları daha genç olan yetişkinlerin yaşları daha ileri olan yetişkinlerle karşılaştırıldığında, mesleki yönelimli eğitim faaliyetlerinde daha fazla istemde bulunduğunu göstermektedir.

Ölçeğin, "Kendini Geliştirmek" alt boyutunda 25-34 yaş ( $\bar{x}=2,73$ )arasında olan katılımcıların 65 yaş ve üstü $(\bar{x}=1,75)$ olan katılımcılara nazaran HEM'lerde yürütülen eğitim faaliyetlerine kendini geliştirmeyle ilişkili nedenlerle daha fazla istemde bulundukları görülmektedir. Bu veriler, 25-34 yaş aralığında olan katılımcıların eğitim istemlerinin, 65 yaş üstündekilere göre daha çok kendini geliştirmek yönünde olduğunu ortaya koymaktadır. Yine, ölçeğin “Ekonomik" alt boyutunda; 35-54 yaş ( $\bar{x}=2,58)$ arasında olan katılımcıların 65 yaş ve üstü $(\bar{x}=1,43)$ olan katılımcılarla karşılaştırıldığında, HEM'lerdeki eğitim faaliyetlerine ekonomik nedenlerle daha fazla istemde bulundukları gözlenmektedir. Bu veri, orta yaş grubunda yer alan katılımcıların ekonomik nedenlerle, genç ve yaşlı yetişkin grubunda yer alan yetişkinlerle karşılaştıııldığında ekonomik nedenlerle, HEM"erdeki eğitim faaliyetlerine daha çok istemde bulunduklarını göstermektedir.

Katılımcıların medeni durumları ile eğitim istemleri arasındaki ilişkiyi ortaya koymaya yönelik $t$ testi sonuçları Tablo 6'da verilmiştir.

Tablo VI

Katılımclların Medeni Durumlarına Göre Eğitim İstemlerine İlişkin T Testi Sonuçları

\begin{tabular}{lcccccc}
\hline Boyut & Medeni Durum & $\mathbf{N}$ & $\bar{x}$ & ss & $\mathbf{t}$ & $\mathbf{p}^{*}$ \\
\hline \multirow{2}{*}{ Ekonomik } & Evli & 193 & 2,44 & 1,27 & \multirow{2}{*}{, $012^{*}$} \\
& Bekar & 54 & 2,11 & 1,03 & &, 52 \\
\hline
\end{tabular}

${ }^{*} \mathrm{p}<0,05$

Tablo 6'da yer alan verilere göre, katılımcıların medeni durumları ile eğitim istemleri arasındaki ilişkiye ilişkin veriler incelendiğinde, ölçeğin "Sosyal", "Mesleki", "Kendini Geliştirmek" ve "Kişisel” alt boyutları bakımından anlamlı bir fark gözlenmezken, "Ekonomik" [ $\left.\mathrm{t}_{(245)}=2,52 ; \mathrm{p}<0,012\right]$ alt boyutu göre anlamlı bir fark olduğu görülmektedir. Buna göre, Evli $(\bar{x}=2,44)$ olan katılımcilar, Bekar $(\bar{x}=2,11)$ olan katılımcilarla karşılaştırıldığında, HEM'lerdeki eğitim faaliyetlerine daha fazla istemde bulundukları gözlenmektedir.

Katılımcıların, kendilerinin öğrenim düzeyleri ile eğitim istemleri arasındaki ilişkiyi ortaya koymaya yönelik yapılan ANOVA testi sonuçları Tablo 7'de verilmiştir. 
Yetişkinlerin Halk Eğitim Merkezlerindeki...

Tablo VII

Katılımcıların Öğrenim Düzeyine Göre Eğitim İstemlerine İlişkin Tek Yönlü ANOVA Testi Sonuçları

\begin{tabular}{|c|c|c|c|c|c|c|c|}
\hline Boyut & Öğrenim Düzeyi & $\mathbf{N}$ & $\bar{x}$ & ss & F & $\mathrm{p}^{*}$ & Anlamlı Fark (Tukey HSD) \\
\hline \multirow{7}{*}{ Sosyal } & $\begin{array}{l}\text { Okuma yazma biliyor ancak } \\
\text { bir okul bitirmemiş (1) }\end{array}$ & 12 & 3,51 & 1,02 & \multirow{7}{*}{4,38} & \multirow{7}{*}{, $001^{*}$} & \multirow{7}{*}{$\begin{array}{l}2-5 \\
3-5\end{array}$} \\
\hline & İlkokul (2) & 53 & 3,23 & 1,10 & & & \\
\hline & Ortaokul (3) & 36 & 3,05 & 1,12 & & & \\
\hline & Lise (4) & 57 & 3,46 & 0,73 & & & \\
\hline & Üniversite (5) & 83 & 3,77 & 0,73 & & & \\
\hline & Lisansüstü (6) & 6 & 3,44 & 1,26 & & & \\
\hline & Toplam & 247 & 3,46 & 0,94 & & & \\
\hline \multirow{7}{*}{ Ekonomik } & $\begin{array}{l}\text { Okuma yazma biliyor ancak } \\
\text { bir okul bitirmemiş (1) }\end{array}$ & 12 & 2,36 & 1,34 & \multirow{7}{*}{6,01} & \multirow{7}{*}{, $000^{*}$} & \multirow{7}{*}{$\begin{array}{l}2-5 \\
4-5\end{array}$} \\
\hline & İlkokul (2) & 53 & 2,92 & 1,31 & & & \\
\hline & Ortaokul (3) & 36 & 2,44 & 1,26 & & & \\
\hline & Lise (4) & 57 & 2,54 & 1,14 & & & \\
\hline & Üniversite (5) & 83 & 1,88 & 1,07 & & & \\
\hline & Lisansüstü (6) & 6 & 1,44 & 0,69 & & & \\
\hline & Toplam & 247 & 2,35 & 1,24 & & & \\
\hline
\end{tabular}

${ }^{* \mathrm{p}<0,05}$

Tablo 7'deki analiz sonuçlarına göre, katılımcıların kendilerinin öğrenim düzeyi ile eğitim istemleri arasında ölçeğin, "Sosyal" [F (5-241)= 4,38; p<0,05], "Ekonomik" [F(5-241=6,01; $\mathrm{p}<0,01$ ] alt boyutlarının puan ortalamaları arasında istatistiksel olarak anlamlı bir farklılık bulunurken "Mesleki", "Kendini Geliştirmek" ve "Kişisel" alt boyutları arasında ise anlamlı bir farklılık gözlenmemiştir. Farklılığın hangi gruplar arasında olduğunu belirlemek amacıyla Post Hoc testlerinden Tukey HSD testi yapılmıştır. Yapılan analiz sonuçları dikkate alındığında, ölçeğin, "Sosyal" alt boyutunda öğrenim düzeyi Üniversite $(\bar{x}=3,77)$ olan katılımcılar, öğrenim düzeyi İlkokul ( $\bar{x}=3,23)$ olan katılımcılarla ile öğrenim düzeyi Ortaokul $(\bar{x}=3,05)$ olan katılımcılarla karşılaştırıldığında, sosyal nedenlerle HEM'lerdeki eğitim faaliyetlerine yönelik daha fazla istemde bulunmaktadır. Söz konusu bu veriye dayanarak yetişkinlerin eğitim düzeyi arttıkça, sosyal nedenlerle HEM'lerdeki eğitim faaliyetlerine daha fazla bir istemde bulundukları söylenebilir. Yine, Tablo 7'deki analiz sonuçları dikkate alındığında, ölçeğin, "Ekonomik" alt boyutunda ise öğrenim düzeyi İlkokul Mezunu $(\bar{x}=2,92)$ olan ve öğrenim düzeyi Lise mezunu $(\bar{x}=2,54)$ olan katılımclların, öğrenim düzeyi Üniversite mezunu $(\bar{x}=1,88)$ olanlara göre HEM'lerdeki eğitim faaliyetlerinde ekonomik nedenlere istemde bulunmaları daha fazladır. Bu veri, katılımcıların eğitim düzeyi düştükçe, ekonomik gerekçelerle, HEM'lerdeki eğitim faaliyetlerine daha fazla bir istemde bulunmaktadır.

Katılımcıların mesleki durumuna göre istemleri arasındaki ilişkiyi ortaya koymaya yönelik yapılan ANOVA testi sonuçları Tablo 8'de verilmiştir.

\section{Tablo VIII}

Katılımclların Mesleki Durumuna Göre Eğitim İstemlerine İlişkin Tek Yönlü ANOVA Testi Sonuçları

\begin{tabular}{|c|c|c|c|c|c|c|c|}
\hline Boyut & Mesleki Durum & $\mathbf{N}$ & $\bar{x}$ & ss & $\mathbf{F}$ & $\mathrm{p}^{*}$ & Anlamlı Fark (Tukey HSD) \\
\hline \multirow{9}{*}{ Mesleki } & Memur/Memur Emeklisi (1) & 44 & 2,02 & 1,04 & 3,67 & \multirow{9}{*}{, $001^{*}$} & \multirow{9}{*}{$\begin{array}{l}1-6 \\
1-8 \\
2-6 \\
2-8\end{array}$} \\
\hline & İşçi/İşçi Emeklisi (2) & 40 & 2,48 & 1,19 & & & \\
\hline & Çiftçi (3) & 2 & 2,38 & 1,12 & & & \\
\hline & Serbest meslek (4) & 15 & 2,20 & 1,10 & & & \\
\hline & Esnaf/Tüccar (5) & 2 & 1,13 & 0,18 & & & \\
\hline & İşsiz (6) & 14 & 2,70 & 1,28 & & & \\
\hline & Ev Kadını (7) & 117 & 5,00 & 0,00 & & & \\
\hline & Diğer (8) & 13 & 2,95 & 1,25 & & & \\
\hline & Toplam & 247 & 2,41 & 1,13 & & & \\
\hline & Memur/Memur Emeklisi (1) & 44 & 2,75 & 1,11 & 4,53 & \multirow{4}{*}{, $000^{*}$} & \multirow{4}{*}{$\begin{array}{l}1-5 \\
1-6\end{array}$} \\
\hline & İşçi/İşçi Emeklisi (2) & 40 & 2,45 & 1,16 & & & \\
\hline & Çiftçi (3) & 2 & 1,77 & 1,11 & & & \\
\hline Kendini Geliştirmek & Serbest meslek (4) & 15 & 1,96 & 0,93 & & & \\
\hline
\end{tabular}




\begin{tabular}{|c|c|c|c|c|c|c|c|}
\hline & Esnaf/Tüccar (5) & 2 & 3,17 & 0,24 & & & $2-5$ \\
\hline & İşsiz (6) & 14 & 2,02 & 1,01 & & & \multirow{2}{*}{$\begin{array}{l}2-6 \\
7-5\end{array}$} \\
\hline & Ev Kadını (7) & 117 & 3,00 & 0,94 & & & \\
\hline & Diğer (8) & 13 & 2,64 & 1,18 & & & \multirow[t]{2}{*}{$7-6$} \\
\hline & Toplam & 247 & 2,71 & 1,29 & & & \\
\hline \multirow{9}{*}{ Ekonomik } & Memur/Memur Emeklisi (1) & 44 & 2,05 & 1,31 & 4,28 & \multirow{9}{*}{, $000^{*}$} & \multirow{9}{*}{$\begin{array}{l}1-7 \\
2-7\end{array}$} \\
\hline & İşçi/İşçi Emeklisi (2) & 40 & 2,35 & 1,24 & & & \\
\hline & Çiftçi (3) & 2 & 2,48 & 1,19 & & & \\
\hline & Serbest meslek (4) & 15 & 2,38 & 1,12 & & & \\
\hline & Esnaf/Tüccar (5) & 2 & 2,20 & 1,10 & & & \\
\hline & İşsiz (6) & 14 & 1,13 & 0,18 & & & \\
\hline & Ev Kadını (7) & 117 & 2,70 & 1,28 & & & \\
\hline & Diğer (8) & 13 & 5,00 & 0,00 & & & \\
\hline & Toplam & 247 & 2,95 & 1,25 & & & \\
\hline
\end{tabular}

${ }^{*} \mathrm{p}<0,05$

Tablo 8'deki analiz sonuçları dikkate alındığında, katılımcıların kendilerinin mesleki durum değişkenleri ile eğitim istemleri arasındaki ilişkiye yönelik olarak ölçeğin, "Mesleki" [F(7-239)=4,81; $\mathrm{p}<0,05]$, "Kendini Geliştirmek" [F(7-239)=4,53; $\mathrm{p}<0,01]$ ve "Ekonomik" [F(7-239)=4,28; $\mathrm{p}<0,01]$ alt boyutları puanı ortalamaları arasında istatistiksel olarak anlamlı bir farklılık bulunmaktadır. Bununla birlikte "Sosyal" ve "Kişisel" alt boyutları anlamlı bir farklılık göstermemektedir. Farklılığın hangi gruplar arasında olduğunu belirlemek amacıyla Post Hoc testlerinden Tukey HSD testi yapılmıştır. Buna göre ölçeğin "Mesleki" alt boyutunda mesleki durumları İşsiz ( $\bar{x}=2,70)$ olanlalar ile Diğer $(\bar{x}=2,95)$ konumunda olan katılımcilar, Memur/Memur Emeklisi $(\bar{x}=2,02)$ olan katılımclara göre HEM"lerdeki eğitim faaliyetlerine daha fazla istemde bulunmaktadır.

Ölçeğin, "Kendini Geliştirmek" alt boyutunda mesleki durumları Esnaf/Tüccar $(\bar{x}=3,17)$ olanlar, Memur/Memur Emeklisi ( $\bar{x}=2,75)$ olan katılımcilardan; Memur/Memur Emeklisi ( $\bar{x}=2,75)$ olanlar da mesleki durumu İşsiz $(\bar{x}=2,02)$ olan katılımcılara göre kendilerini geliştirmeye yönelik eğitim faaliyetlerine daha fazla istem göstermektedir. Mesleki durumları bakımından Esnaf/Tüccar $(\bar{x}=3,17)$ olan katılımcılar, İşçi/Isçi Emeklisi $(\bar{x}=2,45)$ olan katılımcılardan, İşçi/İşçi Emeklisi $(\bar{x}=2,45)$ olan katılımcılar ise İşsiz $(\bar{x}=2,02)$ durumunda olan katılımcılardan daha fazla kişisel gelişimle ilgili eğitim faaliyetlerine istemde bulundukları gözlenmektedir. Diğer yandan, Esnaf/Tüccar $(\bar{x}=3,17)$ konumunda olanlar İşsiz $(\bar{x}=2,02)$ olanlardan; ev kadını $(\bar{x}=3,00)$ olanlarında da İşsiz $(\bar{x}=2,02)$ olanların kişisel gelişimle ilgili eğitimlere daha fazla istemde bulundukları görülmektedir. Araştırma ölçeğinin alt boyutlarından "Ekonomik" boyutunda ise mesleki durumu mesleki durumu Ev kadını olan $(\bar{x}=3,00)$ olan katılımclar mesleki durumları Memur/Memur Emeklisi $(\bar{x}=1,31)$ ve İşçi/Iş̧̧i Emeklisi $(\bar{x}=1,24)$ olan katılımcılarla karşılaştırıldığında HEM'lerdeki eğitim faaliyetlerine istemlerinin fazla olduğu anlaşılmaktadır. Bu bulgu, HEM'lerdeki eğitim faaliyetlerine istemde bulunan kadınların daha çok ekonomik nedenlerle istemde bulunduğunu göstermektedir.

Katılımcıların çalışma durumları değişkenleri ile eğitim istemleri arasındaki ilişkiye yönelik yapılan t testi sonuçları Tablo 9'da verilmiştir.

Tablo IX

Katılımcıların Çalışma Durumuna Göre Ĕ̆itim İstemlerine İlişkin T Testi sonuçları

\begin{tabular}{llccccc}
\hline Boyut & Çalışma Durumu & $\mathbf{N}$ & $\bar{x}$ & ss & t \\
\hline \multirow{2}{*}{ Ekonomik } & Çalışıyor & 98 & 2,00 & 1,08 & $\mathbf{p}^{*}$ \\
& Çalışmiyor & 149 & 2,57 & 1,29 & 5,02 \\
\hline
\end{tabular}

${ }^{{ }^{p} \mathrm{p}<0,05}$

Tablo 9'daki analiz sonuçları incelendiğinde, katılımcıların işgücü piyasasında aktif olarak çalışıp çalışma durumları ile eğitim istemleri arasında ölçeğin "Sosyal", "Mesleki", "Kendini Geliştirmek", ve "Kişisel" alt boyutları arasında anlamlı bir ilişki gözlenmez iken "Ekonomik" [ $\mathrm{t}(245)=5,02 ; \mathrm{p}<0,26]$ alt boyutu arasında anlamlı bir ilişki gözlenmektedir. Buna göre, ölçeğin "Ekonomik" alt boyutunda işgücü piyasasında aktif olarak çalışmayanlar $(\bar{x}=2,57)$ çalışanlarla $(\bar{x}=2,00)$ karşılaştırıldığında, çalışmayan bireyler HEM'lerdeki 
eğitim faaliyetlerine ekonomik nedenlerle daha fazla istemde bulunmaktadırlar.

Katılımcıların aylık gelir durumuna göre eğitim istemlerini ortaya koymaya yönelik ANOVA testi sonuçları Tablo 10 'da verilmiştir.

Tablo X

Katılımcıların Aylık Gelir Durumuna Göre Ĕ̆itim İstemlerine İlişkin Tek Yönlü ANOVA Testi Sonuçları

\begin{tabular}{|c|c|c|c|c|c|c|c|}
\hline Boyut & Aylık Gelir & $\mathbf{N}$ & $\bar{x}$ & ss & $\mathbf{F}$ & $\mathrm{p}^{*}$ & Anlamlı Fark (Tukey HSD) \\
\hline \multirow{6}{*}{ Ekonomik } & 1500 TL ve altı (1) & 35 & 2,90 & 1,43 & \multirow{6}{*}{4,56} & \multirow{6}{*}{, $001^{*}$} & \multirow{6}{*}{$\begin{array}{l}1-3 \\
1-5 \\
2-5\end{array}$} \\
\hline & $1501-2000(2)$ & 71 & 2,66 & 1,27 & & & \\
\hline & $2001-3000(3)$ & 57 & 2,16 & 0,98 & & & \\
\hline & $3501-4000(4)$ & 37 & 2,05 & 1,12 & & & \\
\hline & 5000 TL ve üzeri (5) & 47 & 1,91 & 1,17 & & & \\
\hline & Toplam & 247 & 2,35 & 1,24 & & & \\
\hline
\end{tabular}

${ }^{* \mathrm{p}<0,05}$

Tablo 10'daki analiz sonuçlarına göre, katılımcıların aylık gelir durumları ile ölçeğin "Ekonomik" alt boyutu $[\mathrm{F}(4-242)=6,34 ; \mathrm{p}<0,05]$ puanı ortalamaları arasında istatistiksel olarak anlamlı bir farklılık bulunmakta olup "Sosyal", "Mesleki", "Kendini Geliştirmek" ve "Kişisel" boyutlarında anlamlı bir farklılık göstermemektedir. Farklılığın hangi gruplar arasında olduğunu belirlemek amaciyla, Post Hoc testlerinden Tukey HSD testi yapılmıştır. Buna göre aylık gelir durumları 1500 TL ve altı $(\bar{x}=2,90)$ olan katılımcılar, aylık geliri 2001-3000 TL ( $\bar{x}=2,16)$ ile aylık geliri 5000 TL ve üzeri $(\bar{x}=1,91)$ katılımcllardan; aylık geliri 1501-2000 TL $(\bar{x}=2,66)$ olan katılımcilar, yine aylık geliri 5000 TL ve üzeri $(\bar{x}=1,91)$ olan katılımcılardan daha fazla HEM'lerdeki eğitim faaliyetlerine istemde bulunmaktadır. Bu bulgu, katılımcıların gelir düzeyi düştükçe ekonomik gerekçelerle HEM'lerdeki eğitim faaliyetlerine daha çok istemde bulunduğunu göstermektedir.

Katılımcıların hanedeki kişi sayısına göre eğitim istemlerini ortaya koymaya yönelik ANOVA testi sonuçları Tablo 11'de verilmiştir.

\section{Tablo XI}

Katılımcıların Hanelerindeki Birey Sayısına Göre Eğitim İstemlerine İlişkin Tek Yönlü ANOVA Testi Sonuçları

\begin{tabular}{|c|c|c|c|c|c|c|c|}
\hline Boyut & Kişi sayısı & $\mathbf{N}$ & $\bar{x}$ & ss & $\mathbf{F}$ & $\mathrm{p}^{*}$ & Anlamlı Fark (Tukey HSD) \\
\hline \multirow{8}{*}{ Mesleki } & $1(1)$ & 17 & 1,54 & 0,77 & \multirow{8}{*}{2,64} & \multirow{8}{*}{, $009^{*}$} & \multirow{8}{*}{$\begin{array}{l}1-4 \\
1-7\end{array}$} \\
\hline & $2(2)$ & 39 & 2,56 & 1,13 & & & \\
\hline & $3(3)$ & 63 & 2,43 & 1,18 & & & \\
\hline & $4(4)$ & 69 & 2,74 & 1,22 & & & \\
\hline & $5(5)$ & 37 & 2,36 & 1,15 & & & \\
\hline & $6(6)$ & 9 & 1,94 & 1,07 & & & \\
\hline & 7 ve daha fazla (7) & 13 & 2,98 & 1,31 & & & \\
\hline & Toplam & 247 & 2,48 & 1,19 & & & \\
\hline
\end{tabular}

${ }^{*} \mathrm{p}<0,05$

Tablo 11'deki verilere göre katılımcıların evde yaşayan kişi sayısı ile ölçeğin "Mesleki" alt boyutu $[\mathrm{F}(8-238)=2,64 ; \mathrm{p}<0,05]$ arasında istatistiksel olarak anlamlı bir farklılık bulunmaktadır. Bununla birlikte "Sosyal", "Ekonomik", "Kendini Geliştirmek" ve "Kişisel" alt boyutlarında anlamlı bir farklılık göstermemektedir. Farklılığın hangi gruplar arasında olduğunu belirlemek amacıyla Post Hoc testlerinden Tukey HSD testi yapılmıştır. Buna göre, hanedeki kişi sayısı dört $(\bar{x}=2,74)$ ile yedi ve üzeri $(\bar{x}=2,98)$ olan katılımcıların, hanedeki kişi sayısı bir olan $(\bar{x}=1,54)$ katılımcılara göre HEM'lerdeki eğitim faaliyetlerine mesleki nedenlerle istemde bulunmaları daha fazladır.

\section{Sonuç ve Tartışma}

$\mathrm{Bu}$ araştırmada, HEM'lerdeki eğitim faaliyetlerine katılan yetişkinlerin eğitim istemleri üzerinde belirleyici olan boyutları ve boyutlarla ilişkili değişkenlerin belirlenmesi amaçlanmıştır. Araştırmadan, elde edilen sonuçlara göre, yetişkin bireylerin eğitim faaliyetlerine olan istemlerinde daha çok "Sosyal", "Mesleki, "Kendini Geliştirmek" ve "Ekonomik" nedenler belirleyici olmaktadır. Yetişkinlerin bu yöndeki istemleri 
üzerinde cinsiyet, yaş, medeni durum, öğrenim düzeyi, mesleki durum, çalışma durumu, aylık gelir ve hanedeki birey sayısı bakımından anlamlı bir farklılaşma bulunmaktadır.

Araştırma bulguları incelendiğinde yetişkinlerin, ölçeğin alt boyutları arasında yer alan "Sosyal" alt boyutundaki maddelere daha fazla katılım gösterdikleri belirlenmiştir. Bu alt ölçekte yer alan maddeler "Yeni şeyler öğrenmek", "Çevresindekilere daha faydalı olmak", "Ev dışında faaliyetlerde bulunmak", "Boş zamanları değerlendirmek", "Yeni insanlarla tanışmak", "Arkadaşlarla ortak bir faaliyet içinde bulunmak" ile ilgilidir. Bunun nedeni, insanın sosyal bir varlık olması ve bunun sonucunda diğer insanlarla sürekli bir bağ kurmak ve etkileşim içinde olmak istemesiyle açılanabilir. Her ne kadar araştırmada, yetişkin insanların ilerleyen yaşla birlikte sosyal gereksinimlerinin artığına ilişkin herhangi bir bulgu olmamakla birlikte, böylesi bir gereksinimin de yetişkin insanları bu sürece ittiği söylenebilir. Ünal'ın (1996) da belirttiği gibi bireyler, toplumsallaşma adına çeşitli eğitimsel faaliyetlere katılımda bulunabilirler. Bu katılımların arkasında farklı bireylerle iletişime geçmeye, sosyal çevre oluşturmaya, ait olma/özdeşleşme, güç sağlama, sosyal kimlik edinme, toplumsal konum edinme, kendilerini güvende hissetme, benzerleriyle bir arada olarak yalnızlıtan kurtulmaya çalışma yer almaktadır (Ünal, 1996; Zencirkıran, 2018). Böylelikle, sosyal yönlerini destekleyici eğitimlere katılan bireylerin sosyal yönleri daha güçlü olmakta, kendi yaşam döngülerinde ve içinde bulundukları toplumsal çevrelerde olumlu değişiklikler yaratabilmektedirler (Geray, 2002).

Yetişkinlerin en az katılım sağladığı alt boyut ise "Ekonomik" alt boyuttur. Belirtilen boyut içinde "Kursiyerlere verilen ekonomik destekten yararlanmak", "Maddi kazanç elde etmek", "Çeyizlik ürünleri ucuza mal etmek" maddeleri yer almaktadır. İSK'ye göre, bireyler gelecekteki elde edeceği ekonomik yararları göz önünde bulundurarak bazı eğitim faaliyetlerine daha fazla istemde bulunabilir ve bu doğrultuda eğitime harcamaya yapmaya daha istekli olurlar (Aşır, 2011; Serin, 1979; Ünal, 1996; Yolcu, 2011b). Ancak bu araştırmada yetişkin bireylerin diğer alt boyutlarla karşılaştırıldığında ekonomik nedenlerle HEM'lerdeki eğitim faaliyetlerinde daha az istemde bulunmalarının nedeni her on katılımcıdan yaklaşık sekizinin 35 yaş ve üzerinde olmalarıyla açıklanabilir.

Kişisel özelliklerle ilgili en önemli değişkenlerden biri de yetişkinin cinsiyetidir. Araştırmada, yetişkinlerin cinsiyet değişkenine göre erkeklerden daha ziyade kadınların HEM'lerdeki eğitim faaliyetlerine ekonomik nedenlerle daha fazla istemde bulundukları gözlenmiştir. Bunun nedeni, ekonomik bağımsızlığını kazanarak toplumda güçlü bir konuma sahip olma isteğiyle açılanabilir. Bu bulgu, alanyazında yapılan araştırmaların bulgularıyla örtüşmektedir (Aşır, 2011; Ayhan, 1990, Geray, 2002; Kurnaz, 1996). Geray (2002) araştırmasında, kadınların hayatlarında değişime yol açacak onlara fırsatlar sunacak eğitimlere daha çok yöneldiğini tespit etmiştir. Ayhan (1990), kadınların yetişkin eğitim faaliyetlerine katılma nedenlerinin özel gereksinimlerini karşılamak ve ekonomik gelir elde etmek olduğunu belirlemiştir.

Yetişkinlerin yaşları arttıkça HEM'lerdeki eğitim faaliyetlerine "Mesleki, "Kendini Geliştirmek", "Kişisel Gelişim" ve "Ekonomik" nedenlerle daha az istemde bulunmaktadır. Araştırmada ulaşılan bu bulgu, alanyazında yapılan araştırmalarla tutarlıdır (Boeren ve diğerleri, 2010; Creighton ve Hudson, 2002; Rubenson, 2007; TÜIK, 2019). Yetişkinlerin yaşı ilerledikçe eğitim faaliyetlerine katılmalarını sınırlandıran birkaç neden bulunmaktadır. Bunlardan biri, bazı yetişkinlerin öğrenmeyi çocukların bir sorunu olarak görmesidir. İkincisi, bazı yetişkinlerin de göz sağlığı ve diğer sağlık sorunları yaşamış olmasıdır (Onchari, 2016). Üçüncüsü, işverenlerin daha ileri yaşa sahip olan yetişkinlerle ilgili olarak işgücü piyasasında daha az uzun vadeli beklentileri olmamasıdır. Dolayısıyla bu durum, yetişkin bireylerin işle ilgili becerilerine yatırım yapmalarını daha az cazip hale getirmektedir. Üstelik maliyetler, muhtemelen diğer yaş gruplarıla karşılaştırıldığında daha yüksektir. Ancak, ileri yaştaki yetişkinlerin edindikleri yeni mesleki bilgi ve becerileri, işgücü piyasasında uzun süre boyunca değerlendiremeyecek olmaları, bu eğitimlerin bireysel faydasını düşürmektedir. Söz konusu bu durum, yaşı ileri olan yetişkinler ve onların işverenlerinin eğitim faaliyetlerine yatırım yapmak için daha az hazır oldukları anlamına gelmektedir. Dördüncüsü ise yaşlıların yeterliklerinin gerekli bir başlangıç düzeyinin altında olması da çoğu kez onların işle ilgili eğitimsel faaliyetlere katılmalarını sınırlandırmaktadır (Boeren ve diğerleri, 2010).

Araştırmada evli olan yetişkinler ile bekar olanların eğitim faaliyetlerine olan istemlerinde bir farklılaşma 
olduğu gözlenmiştir. Buna göre, bekar olan katılımcılar "Kendini Geliştirmek" ile ilgili nedenlerle, evli olanlar ise daha çok "Ekonomik" nedenlerle, HEM'lerdeki eğitim faaliyetlerine istemde bulunmaktadır. Bunun nedeni, bekar ve evli yetişkinlerin toplumsal konumlarına bağlı olarak üstlendikleri ve yerinde getirmek durumunda oldukları görev ve sorumluluklarla açıklanabilir. Burada ulaşılan bulguların aksine, Gür ve Kurt (2011) ilgili araştırmasında, ekonomik nedenlerle evli olanlardan ziyade daha çok bekar ve nişanlı olanların istemde bulundukları gözlenmiştir. Alanyazında yapılan araştırmalar, yetişkin eğitim ile öğrenim düzeyi arasındaki ilişkiyi açık bir biçimde ortaya koymaktadır (Boeren ve diğerleri, 2010; Dinçer ve diğerleri, 2016; Onchari, 2016; TÜIK, 2019).

Meslek, "bir bireyin belli bir bilgi, beceri, yetenek ve deneyim dahilinde sürekli yaptığı iş" olarak tanımlanabilir. Bu doğrultuda, sahip olunan meslek ve bu mesleğe ilişkin nitelikler bireylerin ekonomik durumu üzerinde belirleyicidir. Bundan ötürü, bireyler kendilerini yüksek gelir getirici mesleklere ve bu mesleklere yönelik eğitimlere ilişkin daima yüksek bir istemde bulunurlar (Yılmaz, 2009). Yapılan araştırmalar, bireyin sahip olduğu mesleki konumun yetişkin bireylerin eğitime yönelik istemleri üzerinde belirleyici olduğu yönündedir (Creighton ve Hudson, 2002; Dinçer ve diğerleri, 2016; Rubenson, 2007; Kurnaz, 1996). Alanyazında yapılan araştırmalar, açık işsiz konumunda olan bireylerin mesleki nitelikteki eğitim faaliyetlerine katılma durumlarıyla istihdam arasındaki pozitif ilişkiye dikkat çekmektedir. Örneğin, İrdem'in (2016) ilgili araştırmasında, bireylerin mesleki eğitim faaliyetlerine katılma durumlarının onların istihdam edilme olasılıklarını aksi durumda olanlarla karşılaştırıldığında 1,4 kat artırdığını belirlemiştir. Burada tekrar araştırmaya dönüldüğünde, meslek konumu ev kadını olanların ekonomik nedenlerle daha fazla eğitim isteminde bulundukları gözlenmiştir. Bunun nedenlerinden biri, kadınların aldıkları eğitim sonrası sahip oldukları mesleki niteliklerle işgücü piyasasına dahil olmak istemleriyle açıklanabilir. İkincisi de kadınların gelir getirici bir işe dahil olmalarıly birlikte, aile içinde bir güç elde etmek ve toplum içinde yine var olan statüsünü değiştirme isteğiyle ilgili olabilir. Gür ve Kurt'un (2011) araştırmalarında, ev kadınlarının aile ekonomisine katkıda bulunabilecekleri eğitim faaliyetlerine daha fazla istemde bulundukları belirlenmiştir. Söz konusu bu kadınların, eğitim süreci sonunda sahip oldukları mesleki niteliklerini hemen gelire dönüştürmüş oldukları görülmüştür.

Araştırmada, işgücü piyasasındaki istihdam durumu açık işsiz konumunda olan yetişkinlerin kamu sektöründe çalışanlarla karşılaştırıldığında gerek mesleki nedenlerle gerekse ekonomik nedenlerle HEM'lerdeki eğitim faaliyetlerine daha fazla bir istemde bulundukları belirlenmiştir. Bu durumu, İSK çerçevesinde açılanabilir. Kurama göre, işgücü piyasası her zaman için eğitim düzeyi yüksek olan bireylere yönelik bir istemde bulunur (Ünal, 1996). Dolasıyla, eğitim ile istihdam arasında pozitif bir ilişki vardır. Kim ve diğerleri (2004), son bir yıldır ücretli bir işte çalışanların işgücü piyasasında aktif olarak çalışmayanlarla karşılaştırdıklarında, eğitim faaliyetlerine daha fazla katılmış olduklarını belirlemiş̧lerdir.

Alanyazında yapılan araştırmalar, ailelerin gelir düzeyi ile bireylerin eğitim istemi arasındaki ilişkiye dikkat çekmektedir (Balami ve Sakir, 2014; Holt ve Smith, 2005). Araştırmada ulaşılan bulgular, yukarıda belirtilenler araştırma bulgularıyla tam olarak örtüşmese de yetişkin bireylerin gelir düzeyleri ile HEM'lerdeki eğitim faaliyetlerine hangi nedenlerle istemde bulundukları arasında bir ilişki olduğunu ortaya koymaktadır. $\mathrm{Bu}$ doğrultuda yetişkin bireylerin gelir düzeyi düştükçe, ekonomik gerekçelerle HEM’lerdeki eğitim faaliyetlerine daha çok istemde bulundukları belirlenmiştir. İSK'ye göre en kazançlı yatırım, insana yapılan yatırımdır. Kişi bu kazancı eğitim yolu ile elde eder (Hesapçığlu, 1994). Bireyler, katıldıkları eğitim faaliyetleri sonucunda kabul edilebilir bir gelir elde etmeyi ummaktadır. Bu nedenle düşük gelir grubundaki bireylerin ekonomik nedenlerle eğitim isteminde bulunma gerekçeleri bununla açılanabilir.

Araştırmada, hanedeki birey sayısının yetişkinlerin eğitim istemleri üzerinde belirleyici olduğu gözlenmiştir. Buna göre tek kişilik ailelerden ziyade çekirdek ve geniş ailelerde yaşayan katılımcıların HEM"lerdeki mesleki eğitim içerikli faaliyetlere katılımının daha fazla olduğu belirlenmiştir. Gür ve Kurt'un (2011) yaptığı araştırmada, eğitime katılma isteğinin ailedeki çocuk sayısı ile anlamlı düzeyde farklılaştı̆̆1 bulunmuştur. Tek çocuk sahibi ailelerin eğitime katılma konusunda daha istekli olduğu görülmüştür. Kim ve diğerleri (2004), hanede yaşayan 10 yaşın altında çocukları olan yetişkinlerin, eğitim faaliyetlerine küçük çocuk sahibi olmayanlardan daha fazla katılım olasılıklarını belirlemiştir. 
Yapılan bu araştırmanın bulgu ve sonuçlarında dayanarak iki öneride bulunmak mümkündür. Bunlardan ilki, yetişkin bireyleri yeni şeyler öğrenmeye iten nedenlerin sorgulandığı bir araştırma yapılması gerektiğidir. Bunun nedeni, araştırmaya katılan yetişkinlerin en fazla yeni bir şeyler öğrenmek için HEM'lerde eğitim faaliyetlerine istemde bulunduklarını belirtmiş olmalarıdır. Yapılacak bu araştırma bir anlamda eğitim isteminin özelliklerinin de sorgulanmasını içermiş olacaktır.

Araştırmada kadınların erkeklerle karşılaştırıldığında HEM'lerde yürütülen ekonomik içerikli eğitim faaliyetlerine daha fazla istemde bulunduğu gözlenmiştir. Bu doğrultuda, ekonomik beklentilerle HEM'lerdeki eğitim faaliyetlerine dahil olan kadınların, bu eğitimleri tamamladıktan sonraki süreçteki yaşam döngülerini sorgulamaya yönelik bir araştırma yapılmasının yerinde olacağı düşünülmektedir. Yapılacak olan bu araştırmayla, HEM'lerde verilen bu tür eğitimlerin hem içeriğinin hem de işlevselliğinin gözden geçirilmesi mümkün olacaktır.

\section{Yazar(lar)ın Beyanı}

Araştırmacıların katkı oranı beyanı: Araştırmanın verileri doğrudan birinci yazar tarafından toplanmıştır. Her iki yazar, araştırmanın giriş, yöntem, bulgular, tartışma ve sonuç bölümlerine katkıda bulunmuştur.

Çatışma beyanı: Bu araştırmanın yürütülmesi sürecinde herhangi bir kurum veya kişi ile çıkar çatışması olmamıştır.

Destek ve teşekkür: Bu araştırmanın yürütülmesi sürecinde herhangi bir destek alınmamıştır.

\section{Kaynaklar}

Aksan, H. (1989). Ortaöğretimde talebin belirleyicileri (Yayımlanmamış yüksek lisans tezi). Ankara Üniversitesi, Ankara.

Altunsaray, M. (2000). İmam hatip liselerine talebi etkileyen etmenler (Ankara ili örneği) (Yayımlanmamış yüksek lisans tezi). Ankara Üniversitesi, Ankara.

Aslan, G. (2014). Eğitim Bilimleri yüksek lisans programlarına yönelik talebe ilişkin bir çözümleme. Kuram ve Uygulamada Ĕ̆itim Bilimleri, 14(5), 1777-1805.

Aşır, K.S. (2011). Mamak halk eğitim merkezinde açılan kurslara kadınların eğitime katılma ve terk nedenleri (Yayınlanmamış doktora tezi). Ankara Üniversitesi, Ankara.

Ata, E. (2016). Başkent Halk Eğitimi Merkezi'ndeki mesleki kurslara yetişkinlerin katılım örüntüleri. (Yayınlanmamış yüksek lisans tezi). Ankara Üniversitesi, Ankara.

Ayhan, S. (1988). Halk eğitiminde katılma: Ankara'daki halk eğitimi merkezlerinde açılan kurslara katılanların özellikleri, katılmalarını güdüleyen etmenler ve programa ilişkin görüşleri (Yayınlanmamış doktora tezi). Ankara Üniversitesi, Ankara.

Ayhan, S. (1990). Halk eğitimine katılma ile ilgili araştırmalar. Ankara Üniversitesi Eğitim Bilimleri Fakülte Dergisi, 23(1), 307-332.

Balami, Y. G. ve Sakir, A. (2014) Determinants of adult learners enrolment into open and distance learning institutions in the North East, Nigeria. Journal of Education and Practice, 5(31), 58-63.

Barutçu, P. (1996). Ticaret ve turizm meslek liselerine olan bireysel isteminin incelenmesi (Yayınlanmamış yüksek lisans tezi). Ankara Üniversitesi, Ankara.

Başaran, İ. E. (1996). Türkiye eğitim sistemi. Ankara: Yargıcı Matbaası.

Bingöl, M. (2004). Mesleki ve teknik orta öğretim kurumlarının tekstil eğitimi bölümlerine olan talebi etkileyen etkenler: Ankara ili örneği (Yayınlanmamış yüksek lisans tezi). Gazi Üniversitesi, Ankara.

Birleşmiş Milletler Eğitim, Bilim ve Kültür Örgütü (UNESCO) (1985). Yetişkin eğitim terimleri. F. Oğuzkan (Çev.). Ankara: UNESCO Milli Eğitim Komisyonu.

Boeren, E., Nicaise, I. ve Baert, H. (2010) Theoretical models of participation in adult education: The need for 
Yetişkinlerin Halk Eğitim Merkezlerindeki...

an integrated model. International Journal of Lifelong Education, 29(1), 45-61. doi:10.1080/02601370903471270

Bosworth, B. (2008). The crisis in adult education. Issues in Science and Techology, 24(4). 10 Kasim 2019 tarihinde https://issues.org/bosworth/ adresinden erişildi.

Bülbül, S. (1991). Halk eğitimine giriş. Eskişehir: Açıöŏgretim Fakültesi Yayınları.

Büyüköztürk, Ş. (2010). Sosyal bilimler için veri analizi el kitabı (11. bs.). Ankara: Pegem Akademi.

Büyüköztürk, Ş., Çakmak, E. K., Akgün, Ö. E., Karadeniz, Ş. ve Demirel, F. (2013). Bilimsel araştırma yöntemleri (15. bs.). Ankara: Pegem Akademi.

Celep, C. (2006). Türkiye'de halk eğitimi. M. Hesapçıŏlu ve A. Durmuş (Ed.), Türkiye'de eğitim bilimleri: Bir bilanço denemesi içinde (s. 213-238). Ankara: Nobel Yayın Dağıtım.

Cilasun, S. M., Şeker, S. D, Dinçer, N. N. ve Koru, A. T. (2018). Adult education as a stepping-stone to better jobs: An analysis of the adult education survey in Turkey. Adult Education Quarterly, 68(4), 316-346.

Creighton, S. ve Hudson, L. (2002). Participation trends and patterns in adult education: 1991 to 1999. Erişim adresi: https://nces.ed.gov/pubs2002/2002119.pdf

Creswell, J. W. (2012). Educational research (4. Bs.). New York, NY: Pearson.

Dinçer, N. N, Tekin, K. A. ve Aşkar, P. (2016). Investigation of participation in adult education in Turkey. Compartive and International Education Society, 30(3), 530-548.

Ecevit, Y. (2003). Toplumsal cinsiyetle yoksulluk ilişkisi nasıl kurulabilir? Bu ilişki nasıl çalışılabilir? Cumhuriyet Üniversitesi Tıp Fakültesi Dergisi, 25, 83-88.

Egglestone, C., Stevens, C., Jones, E. ve Aldridge, F. (2018). Adult participation in learning survey 2017. Erişim adresi: https://www.learningandwork.org.uk/wp-content/uploads/2018/08/Adult-Participationin-Learning-Survey-2017.pdf

European Commission (2019). Education and training monitor 2019. Luxembourg: Publications Office of the European Union.

Fraenkel, J. R. ve Wallen, N. E. (2011). How to design and evaluate research in education. New York: McGraw-Hill.

Geray, C. (2002). Halk eğitimi. Ankara: İmaj Yayınevi.

Grummell, B. (2007). The 'second chance' myth: Equality of opportunity in Irish adult education policies. British Journal of Educational Studies, 55(2), 182-201.

Gür, Y. ve Kurt, A. (2011). Türkiye'de ailelerin eğitim ihtiyaçları. Sosyal Politika Çalışmaları Dergisi, 12(7), 33-61.

Hablemitoğlu, Ş. (2005). Toplumsal cinsiyet yazlları. İstanbul: Toplumsal Dönüşüm Yayınları.

Härnqvist, K. (1987). Social demand models. G. Psacharopoulos (Ed.), Economics of education research and studies içinde (s. 356-363). Oxford: Pergamon Press.

Hesapçıŏlu, M. (1994). İnsan kaynakları yönetimi ve ekonomisi. İstanbul: Beta Basın Yayın Dağıtım.

Holt, J. ve Smith, C. (2005). Literacy practices among different ethnic groups: The role of socioeconomic and cultural factors. Reading, Research and Instruction, 44(3), 1-21.

Hovdhaugen, E. ve Opheim, V. (2018) Participation in adult education and training in countries with high and low participation rates: Demand and barriers. International Journal of Lifelong Education, 37(5), 560-577. doi: 10.1080/02601370.2018.1554717

İrdem, E. (2016). İŞKUR tarafından düzenlenen mesleki eğitim kursları itibariyle aktif işgücü piyasası politikalarının etki değerlendirmesi (Yayınlanmamış uzmanlık tezi). Çalışma ve Sosyal Güvenlik Bakanlığı Türkiye İş Kurumu Genel Müdürlüğ̈̈, Ankara. 
Johnstone, J. W. C. (1963). Voluners for learning: A Study of the educational pursuits of American adults. Erişim adresi: https://www.norc.org/PDFs/publications/NORCRpt_89.pdf

Kim, K., Collins, H. M., Williamson, J. ve Chapman, C. (2004). Participation in adult education and lifelong learning: 2000-01 (NCES 2004-050). Erişim adresi: https://nces.ed.gov/pubs2004/2004050.pdf

Kurnaz, K. (1996). Açı yükseköğretime olan bireysel talebini etkileyen etmenlerin incelenmesi: Ankara örneği (Yayımlanmamış yüksek lisans tezi). Ankara Üniversitesi, Ankara.

Machin, S. ve Vignoles, A. (2004). Educational inequality: The widening socioeconomic gap. Fiscal Studies, 25(2), 107-128.

Miser, R. (1987). Halk eğitimi kurs programlarının nicel yapısı- çeşitleri, yaygınlıkları, katılanlar (Yüksek lisans tezi). Ankara Üniversitesi, Ankara.

Miser, R. (1999). Halk eğitimi ve toplum kalkınması. Ankara: Türk Tarih Kurumu Basımevi.

Mutaf, Ş. (1995). Endüstri meslek, teknik Anadolu meslek, Anadolu teknik liselerine olan eğitim talebini etkileyen etkenlerin belirlenmesi (Yayınlanmamış yüksek lisans tezi). Ankara Üniversitesi, Ankara.

Oğuzkan, T. ve Okçabol, R. (1993). Yetişkinlerin öğrenme ilgi ve ihtiyaçları ile öğrenme tecrübeleri: Silivri ilçesi örneği. Eğitim bilimleri birinci ulusal kongresi kitabı. Ankara: Milli Eğitim Basımevi.

Okçabol R. (1996). Halk eğitimi (Yetişkin eğitimi). İstanbul: Der Yayınları.

Oktay, A. (2001). 21. yüzyılda eğitim ve Türk eğitimi sistemi. İstanbul: Sedar Yayıncılık.

Onchari, T. O. (2016). Actors influencing learners enrolment in adult education, in Isinya Sub-County, Kajiado County (Yayımlanmamış yüksek lisans tezi). The University of Nairobi, Kenya.

Özbaran, B. D. (2016). Ortaöğretimde mesleki ve teknik eğitim talebini etkileyen etkenler: İstanbul ili örneği (Yayınlanmamış yüksek lisans tezi). İstanbul Aydın Üniversitesi, İstanbul.

Rubenson, K. (2007). Determinants of formal and informal canadian adult learning insights from the adult education and training surveys. Erişim adresi: http://en.copian.ca/library/research/hrsdc/determinants/determinants.pdf

Sarpkaya, R. (2010). Üniversiteye girişte bireysel eğitim istemini etkileyen etmenler: Adnan Menderes Üniversitesi örneği. Kuram ve Uygulamada Ĕ̆itim Bilimleri, 10(1), 449-488.

Serin, N. (1979). Ĕ̆itim ekonomisi. Ankara: Ankara Üniversitesi Basımevi.

Şavran, G. T. (2012). Nicel ve nitel araştırmalarda kullanılan araştırma teknikleri. T. G. Şavran (Ed.). Sosyolojide araştırma yöntem ve teknikleri içinde (s. 64-104). Eskişehir: Anadolu Üniversitesi Yayını.

Tansel, A. (2002). Determinants of school attainment of boys and girls in Turkey. Economics of Education Review 21(5), 455-470.

Tekin, M. (1988). Ankara ilinde yetişkinleri örgün yetişkin eğitimi programlarına katılmaya güdüleyen etmenler ve yetişkinlerin katılmada karşılaştıkları güçlükler (Yayınlanmamış doktora tezi). Ankara Üniversitesi, Ankara.

Tekin, M. (1991). Halk eğitim merkezleri etkinliklerinin yönetimi. Eğitim ve Bilim Dergisi, 15(82), 36-42.

Tezcan, F. ve Duman, A. (2014). Muğla Halk Eğitimi Merkezi kurslarına katılan yetişkin öğrenenlerin güdüsel yönelimleri. E-international Journal of Educational Research, 5(3), 1-18.

Türkiye İstatistik Kurumu (2012). İstatistiklerle kadın 2012. Ankara: Türkiye İstatistik Kurumu Matbaası.

Türkiye İstatistik Kurumu (2017). Türkiye istatistik kurumu eğitim istatistikleri. Erişim adresi: http://www.resmiistatistik.gov.tr/?q=tr/content/23-e\%C4\%9Fitim-istatistikleri

Türkiye İstatistik Kurumu (2019). Yetişkin eğitim istatistikleri. Erişim adresi: http://www.tuik.gov.tr/PreTablo.do?alt_id=1018 
Ural, O. (1995). Halk eğitimi merkezlerinde açılan kursların amacı ve katılan yetişkin katılımcılar. Marmara Üniversitesi Atatürk Ĕ̆itim Fakültesi Eğitim Bilimleri Dergisi, 7, 303-308.

Ural, O. (2007). Türkiye'de yetişkin eğitiminin bugünkü durumu ve geleceği. M. Altıntaş (Ed.). Öğrenen toplum için yetişkin eğitimi sempozyumu bildiler kitabı içinde (s. 12-42). İstanbul: İSMEK Yayınları

Ural, A. ve Kılıç, İ. (2011). Bilimsel araştırma süreci ve SPSS ile veri analizi (3. bs.). Ankara: Detay Yayınları.

Uysal, M. (2004). Türkiye adalet akademisi eğiticilerin eğitimi temel eğitim programı ders notları. Ankara: Ankara Üniversitesi Sürekli Eğitim Merkezi.

Uysal, M. (2005). Yetişkinlerde öğrenme. Ankara: Ankara Üniversitesi Sürekli Eğitim Merkezi.

Ünal, L. I. (1996). Eğitim ve yetiştirme ekonomisi. Ankara: Epar.

Vatandaş, C. (2007). Toplumsal cinsiyet ve cinsiyet rollerinin algılanışı. Sosyoloji Konferansları, 35, 29-56.

Yıldırım, M. (2009). Hayat boyu öğrenme kapsamında yaygın eğitim ve halk eğitim merkezleri. Ankara: Gazi Kitabevi.

Yıldız, A. (2006). Türkiye'de yetişkin okuryazarlığı: yetişkin okuma- yazma eğitimine eleştirel bir yaklaşım (Yayınlanmamış doktora tezi). Ankara Üniversitesi, Ankara.

Yılmaz, S. (2009). Eğitim sektöründe arz-istem analizi. İktisat Fakültesi Mecmuasl, 47(1-4), 380-381.

Yolcu, H. (2011a). Kız meslek liselerine olan bireysel eğitim istemini etkileyen etkenler: Kastamonu ili örneği. Kuram ve Uygulamada Ĕ̆itim Yönetimi Dergisi, 17(3), 453-483.

Yolcu, H. (2011b). Hanehalkının eğitim harcamalarını etkileyen etmenler: Kuramsal bir çalışma. Mehmet Akif Ersoy Üniversitesi Sosyal Bilimler Enstitüsü Dergisi, 3(5), 12-35.

Yolcu, H. ve Aktaş E. (2018). Bir ölçek geliştirme çalışması: Halk eğitim merkezlerinde yürütülen eğitim programlarına katılan yetişkinlerin toplumsal cinsiyet bağlamında eğitim istemlerinin değerlendirilmesi ölçeği. H. Şahin, A. Temizer ve F. Erdoğan (Ed.), Eğitim bilimlerinde güncel akademik çalışmalar-2018 (s. $313-$ 328) içinde. Montenegro: Ivpe.

Zencirkıran, İ. (2018). Sosyoloji (2. bs.). Bursa: Dora Yayın ve Dağıtım. 


\section{EXTENDED ABSTRACT}

\section{Introduction}

Adult education is a field of education in which the required syllabi, tools, methods, and techniques for the education of adults are developed (Başaran, 1996). In other words, adult education is the activity of education applied with a certain plan by the adult and the educator to achieve certain goals (Uysal, 2004). According to Serin (1979), the demand for education is the opportunity for individuals to be enrolled in formal and non-formal education institutions. There are classifications in the literature that are related to the variables affecting educational demand (Härnqvist, 1987; Ünal, 1996). Yet, these classifications are rather related to the educational demands of individuals/young learners/children who are continuing their formal education, or their families. Thus, it is inevitable that the factors affecting the educational demands of young learners and adults respectively differ on a minor or a major scale. Nevertheless, no systematic classification of the factors that are considered to be determinative on the educational demands of adults was not detected in the literature. It is noteworthy to point out that there are limited number of studies in the literature classifying the factors determining the educational demand of adults indirectly (Ata, 2016; Boeren, Nicaise, and Baert, 2010; Cilasun, Şeker, Dinçer and Koru, 2018; Dinçer, Tekin and Aşkar, 2016; Egglestone, Steandns, Jones and Aldridge, 2018; Rubenson, 2007; TÜIK, 2019).

Education of adult individuals needs to have content that improves their economic, social or cultural shortcomings. It is seen that planned and organized educational services are provided for adults in Turkey to fulfill their needs for education whether they have previously received a formal education, have never entered the formal educational process or have never completed it. These services are crucial for improperly schooled or unschooled individuals to improve their lives (Geray, 2002). With regard to this point, services carried out within the scope of adult education are mostly able to fulfill the deficiencies related to education of adults that do not have enough cultural and economic education formerly (Okçabol, 1996).

There are some previous studies in the literature investigating educational demand in Turkey (Aksan, 1989; Altunsaray, 2000; Barutçu, 1996; Bingöl, 2004; Kurnaz, 1996; Mutaf, 1995; Özbaran, 2016; Tansel, 2002; Yolcu, 2011a). There are also researches performed on adult education from the perspectives of PTC's and PCT educators (Tekin, 1991; Yıldırım, 2009), literacy (Duman, 2004; Yıldız, 2006), public development (Ecevit, 2003; Miser, 1999; Ural, 2007; Vatandaş, 2007), participation (Ayhan, 1990; Ural, 1995), and adult learning (Oğuzkan and Okçabol, 1993; Uysal, 2005). Meanwhile, none of these previous studies, whether they focus on educational demand or adult education, is focused specifically on the educational demands of adults. Therefore, this study is going tofill a gap in the literature, distinct from any previous studies. The present study is considered to provide an insight for future research on the topic with its findings.

\section{Method}

The present study, which aims to reveal the educational demands of adults who are enrolled in PTC courses, is an explanative research conducted with the General Survey Model. The study group consists of adults who are enrolled and active in PCT courses within Ankara Metropolitan Municipality borders in the 2018-2019 educational year. Yet, it has not been possible to detect the exact number of adults actively enrolled in PCT's in all districts within the said borders. Furthermore; a study group consisting of individuals from a total of five districts of Mamak, Altındağ, Keçiören, Yenimahalle, and Çankaya was formed after considering factors such as the large geographical area that the population expands, the time and the costs.

The sample group of the study consists of participants selected via the convenience sampling method. This is a known with the feature that the researcher can save time, money and labor force (Büyüköztürk et al., 2013; Ural and Kılıç, 2011). The said method, although provides the mentioned advantages, also provides unreliable results. Therefore, generalization of the results to the whole population could not be possible (Büyüköztürk et al., 2013; Creswell, 2012; Fraenkel and Wallen, 2011).

\section{Results}

The findings of the research showed that adults affiliate by far the most to the dimension located under 
the "social" sub-category regarding their demands of education. The articles under this sub-category are namely "to learn new things", "to become more beneficial to those around", "to meet new people", "to participate in activities outside the home", "to make use of free time", and "to be a group activity with friends". The least affiliated sub-category is revealed to be the "economic" dimension. This sub-category consists of the articles "benefiting from the financial support given to PCT trainees", "to gain economic income", and "to supply bridal items cheaper".

According to the present data; as the level of education of adults increases, their demands for PCT's' educational services based on social factors tend to increase as well, while as their level of education decreases their demands tend to be economically based. Additionally, job-seeking and unemployed adults also show an economically based demand when they come across active trainees of PCT.

A significant level of difference was detected when the educational demands of adults were analyzed with respect to their monthly income. The demands of the participants who have a monthly income of either lower than 1500 TL or 1500-2000 TL are more economically based than those have a monthly income of 5000 TL or higher. This finding can be explained with the theory of human capital. Another noteworthy correlation was found between the household populations of the participants and the origins of their demands. The participants who have 4 to 7 people in their household are more likely to have demands that are based on professional concerns than those living alone.

\section{Conclusion}

The current study aimedevaluation of the factors affecting adults' demands of education. The study reveals that "social", "professional", "self-improvement", and "economic" reasons are most effective on adults' educational demands. The factors of gender, age, marital status, level of education, professional status, employment status, monthly income, and household population cause differences in the demands of adults with regard to education. 